\title{
The Ability of Banks to Lend to Informationally Opaque Small Businesses
}

\author{
Allen N. Berger \\ Board of Governors of the Federal Reserve System \\ Washington, DC 20551 U.S.A. \\ Wharton Financial Institutions Center \\ Philadelphia, PA 19104 U.S.A. \\ aberger@frb.gov \\ Leora F. Klapper \\ The World Bank \\ Washington, DC 20433 U.S.A. \\ lklapper@worldbank.org \\ Gregory F. Udell \\ Kelley School of Business, Indiana University \\ Bloomington, IN 47405 U.S.A. \\ gudell@indiana.edu
}

Forthcoming, Journal of Banking and Finance, Volume 25, 2001

\begin{abstract}
$\underline{\text { Abstract }}$
We test hypotheses about the effects of bank size, foreign ownership, and distress on lending to informationally opaque small firms using a rich new data set on Argentinean banks, firms, and loans. We also test hypotheses about borrowing from a single bank versus multiple banks. Our results suggest that large and foreign-owned institutions may have difficulty extending relationship loans to opaque small firms. Bank distress appears to have no greater effect on small borrowers than on large borrowers, although even small firms may react to bank distress by borrowing from multiple banks, raising borrowing costs and destroying some relationship benefits.

JEL Classification Numbers: G21, G15, G28, G34, E58

Key words: Banks, Mergers, Foreign ownership, Financial distress, Multiple lenders

The opinions expressed do not necessarily reflect those of the Federal Reserve Board, the World Bank, or their staffs. The authors thank Jalal Akhavein, Emilia Bonaccorsi, George Clarke, Robert Cull, Laura D’ Amato, Chris James, Bob Jennings, Sole Martinez Peria, Margaret Miller, Rick Mishkin, George Pennacchi, Andrew Powell, Rich Rosen, Tony Saunders, Ian Sharpe, Giorgio Szegö, Andy Winton, and the participants of the Australasian Conference in Finance and Banking and the Federal Reserve Bank of Chicago Bank Structure and Competition Conference and seminar participants at University of Illinois, World Bank, New York Federal Reserve Bank, Banca D'Italia, and European Central Bank for helpful comments. We especially thank Guillermo Escudé and the staff at the Central Bank of Argentina for providing and preparing the data.
\end{abstract}

Please address correspondence to Allen N. Berger, Mail Stop 153, Federal Reserve Board, 20th and C Streets. NW, Washington, DC 20551, call 202-452-2903, fax 202-452-5295, or email aberger@ frb.gov. 


\section{Introduction}

An important role of banks is to provide relationship lending services that help resolve problems in providing external finance to informationally opaque small businesses. However, a number of factors may affect the banking system's ability to provide credit to relationship-dependent borrowers in the future. Banking industry consolidation creates large banks that may be oriented toward transactions lending and providing capital market services to large corporate clients. These institutions are also often headquartered at great distances from small business customers and may have difficulty processing locally-based, and often less quantitative, relationship information. International consolidation may compound this problem by creating a distant owner that operates from an entirely different banking environment. Bank financial distress may also be an important determinant of credit availability, as evidenced by the credit crunch in the U.S. and the financial crises in East Asia, Latin America, and elsewhere.

These factors raise policy concerns about the effects of bank mergers and acquisitions (M\&As), foreign entry, and prudential supervision and regulation on the supply of relationship credit. This paper tries to shed light on these issues by testing hypotheses about the effects of bank size, foreign bank ownership, and bank distress on lending to informationally opaque small businesses. Previous research has examined the effects of bank size on small business lending, but there has been very little study of the effects of foreign ownership and distress on lending to small businesses.1 Instead, the prior literature has focused on the effects of foreign ownership and distress on the total business lending of the banks. We provide a relatively complete analysis in which the effects of bank size, foreign ownership, and bank distress are examined and compared using a data set that enables us to focus on informationally opaque small businesses.

We also examine a related set of issues regarding the opacity of small businesses and their ability to obtain bank credit - the choice between borrowing from a single bank versus multiple banks. Specifically, we test related secondary hypotheses about the extent to which the single-bank-versus-

1 Foreign ownership is defined as a branch or subsidiary whose head office is located abroad or in which at least $50 \%$ of its capital is foreign-owned. 
multiple-bank decision depends on the informational opacity of the firm versus the financial distress of its primary bank. This may help reveal whether firms borrow from multiple banks principally to avoid the exploitation of market power versus to avoid the possible withdrawal of credit by distressed banks. The extent to which firms borrow from multiple banks to avoid bank distress-related problems also highlights the social costs of lax prudential supervision and regulation, which may result in costly multiple banking arrangements and loss of benefits from exclusive relationships. There are only a few prior studies on the single-bank-versus-multiple-bank issue.

We use a rich, new data set assembled in part from the Central Bank of Argentina's Central de Deudores or central credit registry, which contains information on individual businesses, their loans, and the identities of their banks. This information is combined with data on the balance sheet and income statements of the individual banks taken from other Central Bank sources. In all, we employ data on 61,295 firms with 195,695 total loans from 115 different banks as of the end of 1998. The data set allows a relatively complete look at the circumstances under which firms borrow from large versus small banks, foreign-owned versus domestically-owned banks, and distressed versus healthy banks, as well as an analysis of which firms borrow from a single bank versus multiple banks.2

Section II reviews the role of banks in relationship lending and gives our main and secondary hypotheses. Section II also reviews the extant empirical literature that has tested these and related hypotheses. In Section III, we give some background information about the Argentinean banking system. Section IV describes the data set and gives our methodology for testing the hypotheses. Section V presents our empirical results. We draw some tentative conclusions in Section VI.

\section{The Role of Banks, Hypotheses to be Tested, and Associated Literature}

\section{II.a. The Role of Banks in Relationship Lending}

Under relationship lending, information is gathered by the lender beyond the relatively transparent data available in the financial statements and other sources readily available at the time of origination. The information is gathered through contact over time with the firm, its owner, and its local

2 This data set is similar to the Italian Central Credit Register, which has been used to address similar questions (e.g., Bonaccorsi di Patti and Gobbi 2000, Detragiache, Garella, and Guiso 2000)). 
community on a variety of dimensions. The lender may gather data from the provision of past loans and other services to the business. Information may also be garnered from contact with the borrower's customers and suppliers, and from the lender's knowledge of the borrower's interaction with the local community. This information is used in making additional decisions over time regarding renewals, additional loans, renegotiations, and monitoring strategies, and is not shared with other potential lenders. The production of relationship information is costly, and the costs are likely to be passed on to the relationship borrowers. We expect informationally opaque firms to be more willing to absorb these costs in order to obtain additional external financing and/or more favorable terms.

At the opposite end of the spectrum is pure transactions lending, under which due diligence and contract terms are based on information that is relatively easily available at the time of origination. Each transaction stands on its own in the sense that information from the relationship, if any, between the lender and the borrower is substantially irrelevant. 3

Theory suggests that financial intermediaries may have comparative advantages in delivering relationship lending in their role as delegated monitors. Empirical evidence suggests that one particular intermediary, the commercial bank, may be best suited for this role. The vast majority of small businesses identify commercial banks as their primary financial institutions, and these businesses typically stay with the same bank for many years. Commercial banks provide a broad range of financial services needed by small businesses, and small businesses tend to cluster their purchases of these services in a single, primary bank with a nearby office. As a result, the primary bank can cull information about borrower creditworthiness from providing both lending services and other types of services, including deposits, trust services, investment management, and payroll processing.4

Empirical evidence also generally suggests that banking relationships affect the pricing and availability of credit, and that small businesses benefit from these relationships. Stronger relationships (strength measured in various ways) are empirically associated with lower loan interest rates (Berger and Udell 1995, Harhoff and Körting 1998, Scott and Dunkelberg 1999, Degryse and van Cayseele 2000),

3 Transactions lending encompasses several different lending technologies, including financial statement lending, relationship lending, asset-based lending, and credit scoring and similar quantitative techniques.

4 See Berger and Udell (1998) for a discussion of the empirical literature that reports these findings. 
reduced collateral requirements (Berger and Udell 1995, Harhoff and Körting 1998a, Scott and Dunkelberg 1999), greater debt seniority for the relationship lenders (Longhofer and Santos 2000), lower dependence on trade debt (Petersen and Rajan 1994, 1995), greater protection against the interest rate cycle (Berlin and Mester 1998, Ferri and Messori 2000) and increased credit availability (Cole 1998, Elsas and Krahnen 1998, Scott and Dunkelberg 1999, Machauer and Weber 2000).5

\section{II.b. Main Hypotheses}

The capacity to deliver relationship lending may differ considerably across banks. Our main hypotheses are that large banks, foreign-owned banks, and distressed banks face barriers in providing this type of lending.

\section{Large-Bank Barriers Hypothesis}

Under the Large-Bank Barriers Hypothesis, large banks tend to have difficulty extending relationship loans to informationally opaque small businesses. This may occur because of Williamsontype organizational diseconomies of providing relationship lending services along with providing transactions lending services and other wholesale capital market services to the large corporate customers generally served by large banking organizations. That is, it may be too costly to provide relationship services to small businesses together with other services to large businesses. Large banks may also be disadvantaged in relationship lending because this type of lending often requires "soft" information that may be difficult to transmit through the communication channels of large organizations (Stein 2001). Efforts to coordinate lending in large institutions could lead to standardized credit policies based on easily observable, verifiable, and transmittable data, which may be antithetical to relationship lending (e.g., Berger and Udell 1998, Scott and Dunkelberg 1999, Haynes, Ou, and Berney 1999, Cole, Goldberg and White 1999, Machauer and Weber 2000). However, these organizational costs may be offset to the extent that diversification reduces Diamond (1984) type delegation costs in large banks (e.g., Strahan and Weston 1998, Black and Strahan 2000).

Large banks may also be disadvantaged in relationship lending because they are more often

5 Not all of this research found that credit terms improve with the strength of the relationship. For example, some found either unclear or negative associations between the length of the relationship and loan rates (Petersen and Rajan 1994, Blackwell and Winters 1997, Angelini, Salvo, and Ferri 1998). 
headquartered at a substantial distance from potential small business borrowers. Relationship lending may require local knowledge that gives locally-owned banks a comparative advantage in this type of lending. Some research found that relationship lending diminishes with "informational distance," or the costs of generating borrower-specific information, which is likely to be associated with physical distance (Hauswald and Marquez 2000).

Most of the relevant empirical studies tend to support the Large-Bank Barriers Hypothesis. Some studies found that large banks tend to devote a lower proportion of their assets to small business lending than smaller institutions (e.g., Berger, Kashyap, and Scalise 1995, Berger and Udell 1996, Peek and Rosengren 1996, Strahan and Weston 1996, Berger, Saunders, Scalise, and Udell 1998). Some studies also found that to the extent that large banks extend small business loans, these banks tend to skew their loans away from relationship-dependent small borrowers. Research found that large banks are associated with low interest rates and low collateral requirements for the small businesses that receive loans (Berger and Udell 1996). Similarly, relative to small banks, large banks more often lend to larger, older, more financially secure businesses - firms that are most likely to receive transactions loans (Haynes, Ou, and Berney 1999). Another study also found that large banks tend to base their small business loan approval decisions more on financial ratios, whereas the existence of a prior relationship with the borrowing firm mattered more to decisions by small banks (Cole, Goldberg, and White 1999). These studies suggest that large banks tend to issue small business loans to relatively safe transactions credits, rather than to relatively risky relationship borrowers that tend to have higher interest rates and collateral requirements. 6

A number of studies also examined the effects of bank M\&As on small business lending (e.g., Keeton 1996, Peek and Rosengren 1998, Strahan and Weston 1998, Berger, Saunders, Scalise, and Udell 1998, Avery and Samolyk 2000, Bonaccorsi di Patti and Gobbi 2000). M\&As involve dynamic effects, such as changes in bank focus or disruptions caused by the consolidation process, as well as changes in

6 These conclusions are based upon the assumption that relationship loans by banks to small businesses are riskier on average than transactions loans to small businesses. However, there are also categories of transactions loans which may be quite risky, such as asset-based loans extended by finance companies (Carey, Post, and Sharpe 1998) and below-investment-grade private placements extended by life insurance companies (Carey, Prowse, Rea, and Udell 1993). 
bank size. These studies usually found that M\&As involving large banking organizations reduced small business lending substantially.

However, other evidence suggests that bank size and consolidation do not necessarily have negative consequences for small business lending. Some of the M\&A studies cited above found that M\&As between small organizations increased, rather than decreased small business lending. Another study examined the probability that small business loan applications will be denied by consolidating banks and other banks in their local markets and found no clear positive or negative effects (Cole and Walraven 1998). Other researchers found that the probability that a small firm obtains a line of credit or pays late on its trade credit does not depend in an important way on the presence of small banks in the market (Jayaratne and Wolken 1999). Another study found that small businesses obtain lines of credit from small banks roughly in proportion to the presence of small banks in the local market, rather than disproportionately more from small banks as might be expected based on the extant literature (Berger, Rosen, and Udell 2001). It was also found that the interest rates charged on small business lines of credit tend to be lower in markets dominated by large banks than in markets dominated by small banks (Berger, Rosen, and Udell 2001). Another study found mixed effects of how small businesses were treated by consolidating banks in terms of satisfying borrowing needs, loan approval/rejection, shopping for lenders, loan rates, etc. (Scott and Dunkelberg 1999).7

Importantly, even if the Large-Bank Barriers Hypothesis is true, the consolidation of the banking industry may not substantially reduce the total supply of credit to informationally opaque small businesses because there may be "external effects" or general equilibrium effects in which other banks react to any reduced supply of credit by the consolidating institutions by increasing their own supplies. That is, although relationship-based small business loans may be dropped by some large banks after

7 Some research has also examined the effects of distance on small business lending. Studies that evaluated the effects of out-of-state bank ownership found small or conflicting effects (e.g., Keeton 1995, Whalen 1995, Berger and Udell 1996, Berger, Saunders, Scalise, and Udell 1998). Other studies found that distance barriers in small business lending may be decreasing over time, perhaps because of improvements in information technology (Cyrnak and Hannan 2000, Petersen and Rajan 2000). Finally, one study found that it is difficult for bank holding companies to control the efficiency of small banks located at a significant distance from their holding company headquarters, consistent with the possibility that small bank activities, possibly including relationship lending, may be difficult to operate from afar (Berger and DeYoung 2001). 
M\&As, other banks or nonbank lenders may pick up some of these loans if they are positive net present value investments. Several recent studies found external effects of bank M\&As in terms of increased lending to small businesses by other incumbent banks in the same local markets that offset at least part of the negative quantity effects of M\&A participants (Berger, Saunders, Scalise, and Udell 1998, Avery and Samolyk 2000, Berger, Goldberg, and White 2001). There may also be an external effect in the form of an increase in de novo entry — new banks that form in markets where M\&As occur - although the evidence is mixed on this issue (Seelig and Critchfield 1999, Berger, Bonime, Goldberg, White 2000).

\section{Foreign-Owned-Bank Barriers Hypothesis}

Under the Foreign-Owned-Bank Barriers Hypothesis, foreign-owned banks are less likely to lend to informationally opaque small businesses than domestically-owned banks. Foreign-owned banks are often large and nearly always are headquartered a considerable distance from local small businesses, and so may suffer size- and distance-related disadvantages in delivering relationship lending services similar to those of large domestically-owned banks. In addition, a foreign-owned bank may be headquartered in a very different market environment, with a different language, culture, supervisory/regulatory structure, and so forth. These market differences may make it costly to gather and process locally-based relationship information and compound the problems associated with size and distance. In our empirical analysis, we distinguish between foreign-owned banks in Argentina that are headquartered in other South American nations versus in other nations, since institutions from the same continent are generally shorter distances from potential borrowers and are from markets with more similar culture and language.

Despite policy concerns about the potential effects of cross-border consolidation on the supply of credit to informationally opaque small businesses, we are unaware of any prior studies that directly measured the effects of foreign bank ownership on lending to small businesses. However, there is some evidence on the more general issue of the strategic focus of foreign-owned institutions. Specifically, studies have found that foreign-owned banking organizations tend to have a wholesale orientation (e.g., DeYoung and Nolle 1996), to buy domestic banks that already have performance problems and so may reduce credit for other reasons (e.g., Peek, Rosengren, and Kasirye 1999), and to lend to large corporate 
affiliates of their customers in their home nation (e.g., Grosse and Goldberg 1991). Finally, one study found that foreign-owned banks tend to have higher proportions of their assets invested in business loans to both domestic and foreign borrowers than domestically-owned banks, although the authors did not have information on small business lending specifically (Stanley, Craig, and McManis 1993).8

There has also been related research on the association between foreign ownership and bank efficiency. Presumably, if differences in market environments create significant barriers to lending to informationally opaque small businesses, these barriers also reduce bank efficiency. Consistent with the Foreign-Owned-Bank Barriers Hypothesis, most studies on this topic found that foreign-owned banks in a host nation are generally less efficient than the domestically-owned banks in that host nation (see Berger, DeYoung, Genay, and Udell 2000 for a review). However, one study found that foreign-owned banks outperform domestically-owned banks in emerging market host nations (Claessens, DemirgücKunt, and Huizinga 2001).

As was the case for the Large-Bank Barriers Hypothesis, even if the Foreign-Owned-Bank Barriers Hypothesis is true, foreign bank entry may not substantially reduce the total supply of credit to opaque small firms because of potential external effects. An increased supply of relationship credit by incumbent domestic banks or de novo entry of domestic banks could offset at least part of any negative supply effects of foreign-owned banks.

\section{Distressed-Bank Barriers Hypothesis}

Under the Distressed-Bank Barriers Hypothesis, banks that are in financial distress are less likely to lend to informationally opaque small businesses (more so than to businesses as a whole). Government supervisors/regulators, depositors and other capital market investors, and/or risk-averse managers may encourage or require distressed institutions to reduce their risk profile in general, and their risk from lending in particular.9 These institutions may reduce relationship lending to informationally opaque small businesses more than other types of loans because the risk of these loans cannot be easily

8 The effects of distance, language, and culture have been observed in other financial phenomena. Recent evidence suggests that these factors may explain the "home bias" effect, in which investors are averse to including foreign stocks in their portfolios (Grinblatt and Keloharju 2001).

9 For example, one study of the banking sectors of Argentina, Chile, and Mexico found that depositors disciplined risky banks by withdrawing their deposits (Martinez Peria and Schmukler 2001). 
verified and quantified for government agents, depositors and other capital market investors, or senior managers. In addition, informationally opaque small businesses may avoid establishing relationships with banks in distress - or banks that are likely to become distressed - because the consequences of the withdrawal of credit is so severe for these firms. A small business that is cut off may incur significant search costs or disruption in finding another lender, and may face less favorable loan terms (e.g., higher rates, greater collateral requirements) until their new relationships mature. In some cases, information problems may prevent them from obtaining new funding.

Contrary to the hypothesis, however, bank distress may affect transactions lending more than relationship lending. Banks may hold onto "captured" relationship borrowers during distress periods to reap future benefits from these relationships (Dell'Ariccia and Marquez 2001). Relationship borrowers may also have more difficulty switching their loans to healthy banks than transactions borrowers when their banks become distressed, so the proportion of loans by distressed banks to opaque small businesses may rise.

The research on the effects of bank distress generally focuses on total business lending, rather than on small business lending. Studies of bank lending behavior generally found that banks that are capital impaired or otherwise distressed tend to reduce business lending. Surveys of banking crises around the world suggested that these crises were often followed by substantial real negative loan growth during and after the crises, but this was often mitigated by government bailouts of the banking systems (Caprio and Klingebiel 1996, Demirgüc-Kunt, Detragiache, and Gupta 2000).10,11

One of the most studied cases of the effects of bank distress on lending is the U.S. "credit

10 In an interesting twist involving two of our hypotheses and using Argentinean data, one study found that the presence of foreign-owned banks may mitigate the effects of national banking crises, with foreign-owned institutions having higher loan growth than domestically-owned banks during crisis periods (Goldberg, Dages, and Kinney 2000). However, again, small and large business lending are included together, making it difficult to evaluate our hypotheses about small business lending.

11 There is also some evidence on the capital-market effects of bank distress and failure on publicly traded firms. The announced insolvency of Continental Illinois Bank greatly reduced the market values of its publicly-traded borrowers, and the announcement of the FDIC rescue had a positive effect on these firms' share prices (Slovin, Sushka, and Polonochek 1993). Related literature found that bank distress can have negative capital market effects on borrowing firms, although the studies varied in the measured severity and permanence of these effects (Chiou 1999, Claessens, Djankov, and Ferri 1999, Djankov, Jindra, and Klapper 2000, Kang and Stulz 2000, Ongena, Smith, and Michalsen 2000). 
crunch" in the early 1990s, in which bank business lending was reduced substantially. Researchers tested whether the decline in lending was the result of tougher supervisory standards in examining bank portfolios (e.g., Peek and Rosengren 1995a, Berger, Kyle, and Scalise, forthcoming), the implementation of Basle-Accord risk-based capital standards (e.g., Berger and Udell 1994, Wagster 1999), higher explicit or implicit regulatory capital standards based on leverage ratios (e.g., Berger and Udell 1994, Peek and Rosengren 1994, 1995b, Hancock, Laing, and Wilcox 1995, Shrieves and Dahl 1995), the depletion of bank capital from loan loss experiences (e.g., Peek and Rosengren 1995b, Hancock and Wilcox 1998), or managerial decisions to reduce risk (e.g., Berger and Udell 1994, Peek and Rosengren 1995b, Hancock and Wilcox 1998, Wagster 1999). Although the results fall short of consensus, they generally found that all of these factors except for implementation of the Basle Accord led to reduced business lending. These studies generally used the total business lending of each bank, rather than separating out small business lending, which is problematic using early 1990s data.

However, one of these studies was able to at least implicitly analyze small business lending. It found that a $\$ 1$ capital decline at a small bank reduced business lending more than a $\$ 1$ capital decline at a large bank, implying a greater reduction in small business lending, since small banks tend to specialize in small business lending (Hancock and Wilcox 1998). The reduction in capital at small banks was also associated with a decline in the health of small businesses in the same state, consistent with the Distressed-Bank Barriers Hypothesis.

As with the prior hypotheses, even if the Distressed-Bank Barriers Hypothesis is true, distress by a number of banks may not substantially reduce the total supply of relationship credit to opaque firms if other healthy banks (domestically- or foreign-owned) step in with positive external effects.

\section{II.c. Secondary Hypotheses}

Our secondary hypotheses concern the conditions likely to result in a firm borrowing from a single bank versus from multiple banks. The main conditions tested are the informational opacity of the firm and whether the firm's primary bank is in financial distress. We identify the primary bank as the bank from which the firm borrows the most.

\section{Single-Bank Firm-Opacity Hypothesis}

The benefits from a bank-borrower relationship stem mainly from having a single bank with 
proprietary information about the borrower, which may make more credit available at lower cost to creditworthy, but informationally opaque, borrowers. However, firms that would benefit from a single banking relationship may still borrow from multiple banks in order to avoid a "hold-up" problem in which a single bank may exploit its market power and extract excessive rents (Rajan 1992). As well, a bank may wish to avoid being locked in as a firm's only lender because of a potential "soft-budgetconstraint" problem in which the firm may be able to coerce the bank to provide additional funds to avoid losses on previously issued credit (e.g., Boot 2000).12 Thus, market power on either side of an exclusive lending relationship may cause problems that result in firms borrowing from multiple banks.13 However, borrowing from multiple banks may be costly (higher transactions costs, duplicated effort, free-rider problems, etc.) and informationally inefficient relative to relationship lending by a single bank. Under the Single-Bank Firm-Opacity Hypothesis, informationally opaque firms are more likely to have a single lender, other things held equal, because the benefits associated with an exclusive lending relationship are more likely to outweigh the costs of information acquisition plus the costs associated with the potential hold-up and soft-budget-constraint problems for these firms. In contrast, transparent firms are more likely to have multiple lenders under this hypothesis to reduce potential market power problems.

Several studies found that smaller firms tend to have single banking relationships and larger firms tend to have multiple banks (e.g., Detragiache, Garella, and Guiso 2000, Machauer and Weber 2000, Ongena and Smith 2000). Another study found that smaller firms are less likely to switch from single to multiple banking providers, and that the probability of switching increases with age (Farinha and Santos 2000). These results are consistent with the Single-Bank Firm-Opacity Hypothesis, since

12 Borrowers may also be reluctant to borrow from multiple banks for reasons of confidentiality. They may fear that private information revealed to their bankers could be leaked to competitors, and may minimize this risk by consolidating their borrowing in a single bank (Bhattacharya and Chiesa 1995).

13 Ironically, market power by a single bank may play a positive role for the small business by allowing the bank to subsidize the borrower in the short term, and then charge higher-than-competitive rates in later periods (Sharpe 1990, Petersen and Rajan 1995). Some studies found that less competition in banking is helpful to small firms and start-ups (Petersen and Rajan 1995, Bonaccorsi di Patti and Dell'Ariccia 2001), but other research suggested more bank competition is helpful (Black and Strahan 2000). These market power benefits, if they occur, are lost or diminished in the event that firms borrow from multiple banks. 
firm size is an inverse indicator of opacity.14 Of course, firm size is associated with many other firm characteristics as well.

\section{Multiple-Bank Bank-Distress Hypothesis}

Under the Multiple-Bank Bank-Distress Hypothesis, informationally opaque firms are more likely to have multiple lenders if their primary bank is in financial distress. Under this hypothesis, an opaque firm borrows from multiple banks to protect itself against the possibility of a future deterioration of credit terms or availability because its primary bank is distressed or fails. A primary bank that is in distress may take a number of actions that are costly to the firm, ranging from higher rates and collateral requirements to a complete cut-off of credit and destruction of the relationship. As discussed above, a withdrawal of credit may have severe consequences for opaque firms in terms of search costs, disruption, unfavorable credit terms, or being unable to obtain replacement funding. Other potential replacement lenders may not be able to distinguish whether the withdrawal of credit was due to the distress of the withdrawing bank versus the creditworthiness of the firm. We acknowledge that the Multiple-Bank Bank-Distress Hypothesis follows Detragiache, Garella, and Guiso (2000), but our hypothesis and tests differ in some important respects, as discussed below.

The Multiple-Bank Bank-Distress Hypothesis has two main empirical predictions. First, informationally opaque firms with primary banks in financial distress are more likely to have multiple bank lenders to protect themselves. If the primary bank were perfectly safe and sound and in no danger of distress, there would be no need to dilute relationship benefits and bear the extra costs of borrowing from multiple banks. Second, under the hypothesis, informationally opaque firms are more likely to have multiple lenders for a given level of primary bank distress. This is because after being cut off by the primary bank, opaque firms are likely to encounter more difficulty in finding additional lenders and/or have to face less favorable loan terms until their new relationships mature.

This second prediction of the Multiple-Bank Bank-Distress Hypothesis runs contrary to the

14 Some of these studies also examined other measures of opacity such as R\&D expenditure and patents, but did not find any significant association (Detragiache, Garella, and Guiso 2000, Farinha and Santos 2000). One study found that switching from single to multiple banks was positively related to poor firm performance (Farinha and Santos 2000), which could be construed as counterevidence to the Single Bank-Firm Opacity Hypothesis, since low firm quality (i.e., high risk) may exacerbate opacity problems. 
main prediction of the Single-Bank Firm-Opacity Hypothesis. Under the Single-Bank Firm-Opacity Hypothesis, more informationally opaque firms are more likely to borrow from a single bank to take advantage of relationship lending benefits, whereas under the Multiple-Bank Bank-Distress Hypothesis, more opaque firms are likely to have multiple bank lenders to insure against the loss of credit or lending terms in the event of having their credit cut off by a distressed or failed bank. Each hypothesis may be true for a different subset of firms, so the measured effect of firm opacity on whether the firm borrows from single versus multiple banks will be taken to be the net effect of these two different hypotheses. However, the measured effects of primary bank distress gives a relatively clean test of the effects of the Multiple-Bank Bank-Distress Hypothesis, since the Single-Bank Firm-Opacity Hypothesis has no prediction about the effect of the primary bank's condition.

Our Multiple-Bank Bank-Distress Hypothesis is similar to, but differs in some important ways from the analysis of Detragiache, Garella, and Guiso (2000). Both studies include measures of firm informational opacity in their empirical applications. However, we emphasize the prediction that more opaque firms are more likely to have multiple lenders as protection against loss of credit or lending term deterioration, while their theoretical model does not give predictions about the effects of opacity. Their model is also much more complex and allows for the possibility that the effects of bank fragility (similar to our concept of bank distress) on the number of banks can go either direction and may depend on other factors, including the degree to which the bank can make recoveries on bad loans. In fact, they found that bank fragility has opposing signs on the probability of borrowing from multiple banks and on the expected number of banks, given that multiple banks are used. In addition, we specify the distress of the firm's primary bank (identified as the bank from which firm has its greatest value of loans), whereas Detragiache, Garella, and Guiso (2000) specified the weighted average of the conditions of all the relationship banks. We argue that the benefits of relationship lending are maximized by borrowing exclusively from the primary bank, so under the Multiple-Bank Bank-Distress Hypothesis, the main reason for choosing additional lenders is problems with the financial health of the primary bank.

A policy implication of the Multiple-Bank Bank-Distress Hypothesis is that some of the longterm benefits of relationship lending may be lost and extra real resource costs associated with multiple lenders may be borne in banking systems in which a high proportion of assets are in institutions that are 
in unsafe, unsound condition. Thus, lax prudential supervision/regulation and lack of market discipline to control bank risk taking could encourage many firms to bear the extra costs of obtaining multiple banks to insure credit availability and terms and lose the benefits of exclusive banking relationships. This is in addition to the well-known costs of financial system fragility and the ex post costs discussed above under the Distressed-Bank Barriers Hypothesis. The additional costs here are the ex ante costs associated with borrowing from multiple banks before credit is withdrawn.

As discussed above, several studies found that smaller firms are more likely to have single banking relationships and larger firms are more likely to use multiple banks. Assuming that size is an inverse measure of informational opacity, this tends to support the Single-Bank Firm-Opacity Hypothesis on net over the Multiple-Bank Bank-Distress Hypothesis. However, as noted, each hypothesis may hold for different subsets of banks. We therefore look to the other empirical prediction of the Multiple-Bank Bank-Distress Hypothesis - that informationally opaque firms with primary banks in financial distress tend to have multiple bank lenders. The extant literature is mixed on this issue. One study using Italian data found that firms that borrowed from banks that were more fragile on average tended to choose a single lender over multiple lenders, but conditional on having chosen multiple lenders, more fragility led to a larger number of banking relationships (Detragiache, Garella, and Guiso 2000). Another study using Italian data found that banks whose borrowers on average borrow from many banks tend to have higher nonperforming loans, depending upon region (Ferri and Messori 2000), yielding some support for the Multiple-Bank Bank-Distress Hypothesis. Another study using Portuguese data, however, found that switching from a single bank lender to multiple bank lenders was not associated with bank distress (Farinha and Santos 2000).

\section{Background Information on the Argentinean Banking System}

Argentina's banking system is unusual in a number of respects, including a relatively large and growing market share for foreign-owned banks and a continued presence but reduced role of state-owned institutions. The current system reflects a number of important changes since the early 1990s. Some of these changes resulted from policy shifts and some resulted from a financial crisis.

Argentina entered the 1990s on the heels of a period of severe hyperinflation. As a result, Argentina implemented its Convertibility Plan, a program that fixed a 1:1 peso-U.S. dollar exchange rate 
and led to the development of a bimonetary financial system that permits the use of $\$$ U.S. for all financial transactions. The Plan also set out an ambitious reform agenda, including a new charter for the Central Bank to increase its independence, privatization of state-owned enterprises, and removal of trade barriers. These measures are often credited with stabilizing the economy and providing a period of strong growth. Argentina moved from hyperinflation in 1989 to less than $1 \%$ inflation in 1998, and the average annual growth of GDP between 1991 and 1998 was more than $6 \%$.

In the 1990s, the banking sector grew even more than the rest of the economy, in part reflecting the resolution of problems of instability and very high inflation of the 1980s. However, growth in both the banking and real sectors was significantly interrupted by the Mexican banking crisis or Tequila crisis in 1994-95 that had substantial contagion effects throughout much of Latin America. The Tequila crisis jeopardized the solvency of many private Argentinean banks and resulted in a significant number of forced mergers and consolidations (Clarke and Cull 1998). As a result, the number of private domestically-owned banks decreased from 182 to 112 and their share of total assets decreased from 66\% to 30\% between December 1991 and December 1998 (Raffin 1999).

During this same time interval, the number of foreign-owned banks increased from 32 to 43 and the market shares of these banks soared - their share of total assets increased from $14 \%$ to $53 \%$, their share of total loans rose from $12 \%$ to $46 \%$, and their share of deposits grew from $17 \%$ to $44 \%$ (Raffin 1999). The increased foreign-owned bank presence reflects not only a flight to quality, but also a trend towards foreign-owned bank presence in Latin America as a whole. This shift to foreign ownership is quite pronounced by world standards - in most countries the banking market shares held by foreignowned banks does not exceed 10\% (Levine 1996).

The aggregate data also suggests some significant differences in lending behavior between foreign- and domestically-owned banks. In 1997, foreign-owned banks allocated almost $95 \%$ of their total credit to borrowers in Buenos Aires, where most of the nation's large businesses are headquartered. In contrast, domestic private and state-owned banks allocated $43 \%$ and $77 \%$ of their total credit, respectively, to provinces outside of Buenos Aires. In addition, foreign-owned banks appeared to lend much more to large-scale projects in manufacturing and utilities than domestically-owned banks. Domestically-owned banks more often lend to primary production sectors, such as food products, wood, 
metal, etc., and retail trade (Cull 1998). Finally, foreign-owned banks tend to be larger, to have better quality loan portfolios, higher net worth, and higher profitability than domestically-owned banks (Clarke, Cull, D’ Amato, and Molinari 1999).

Argentina also has a large presence of state-owned banks, although this has been declining as a matter of policy. Between 1995 and 1996, 15 financial institutions were privatized (Calomiris and Powell 2000). As of 1997, 18 state-owned banks held $31 \%$ of total bank assets and $35 \%$ of total deposits. These banks concentrate on government services, extending a minority of their credit for primary production. Among the domestically-owned banks, the state-owned institutions are among the worst performers in terms of standard criteria, with relatively high percentages of nonperforming loans. The poor performance of these institutions, combined with their allocation of resources to non-private enterprises, suggests that state-owned banks do not grant credit according to wealth-maximizing criteria. Specifically, these banks often have a mandate to lend to certain sectors (such as agriculture) or borrower types, regardless of creditworthiness. State-owned banks in Argentina have been found to exhibit a number of other differences in behavior from privately-owned banks, including having more stagnant loan growth and being less responsive to market signals (Goldberg, Dages, and Kinney 2000). Because of these differences, we treat state-owned banks quite differently from privately-owned banks in our empirical analysis below.

\section{Data Description and Methodology}

In this section, we first describe our data set (subsection IV.a). We then discuss the equations for testing our main hypotheses (subsection IV.b) and secondary hypotheses (subsection IV.c).

\section{IV.a. Data and Summary Statistics}

Our main data source is the Central Bank of Argentina's Central de Deudores or central credit registry, which contains information on individual businesses, their loans, and the identities of their banks. We match these data with financial information on the individual banks from other Central Bank sources. Prior to the Tequila Crisis, the Central Bank had been collecting information on major debtors those with total debt in the financial system above 200,000 pesos - in the Central de Riesgo (Risk Central) for several years. Following the crisis, all supervised financial institutions were required to report on a monthly basis the status of all loans outstanding in excess of 50 pesos. The amount 
outstanding reflects the current balance on the loan, as opposed to the initial amount, which may be considerably greater. Key information supplied by lenders includes the name of the borrower, their taxpayer identification number (QUID), the amount of loans outstanding, the quality category of the loans on a 1-5 scale (measured by number of days past due), and details of any guarantees. Borrowers with more than 200,000 pesos in debt are required to provide additional information, including income and property holdings (for individuals) and balance sheet and employment information (for firms).

We use the data from the Central de Deudores as of the end of 1998. These data are taken from the monthly bank reports as of December 1998, although we use the November or October reports in a few cases in which banks did not report in December. The data set includes information on 61,295 nonfinancial firms with loans from 98 privately-owned banks and 17 state-owned banks.

We exclude data on 19,472 nonfinancial firms that have a state-owned bank as their primary bank (although we include any loans from state-owned banks for borrowers that have a privately-owned institution as their primary bank). We make this exclusion because the objectives of state-owned institutions in Argentina appear to differ significantly from those of privately-owned banks, and our hypotheses are not intended to apply to state-owned institutions. Inclusion of firms with state-owned banks as their primary banks could confound our hypothesis tests because the behavior of these banks may not accord with the wealth-maximization precept that underlies our hypotheses. For example, if large or distressed state-owned banks have a strong mandate to lend to some types of informationally opaque small businesses, this could obscure the measured effects of the Large-Bank Barriers Hypothesis or Distressed-Bank Barriers Hypothesis, respectively. Lending by large or distressed stateowned banks to opaque firms could offset the dearth of lending by large or distressed privately-owned banks to these firms and make these hypotheses appear to be false when they are true.

We also exclude 1,607 firms with total bank loans less than 2,000 pesos. Loans smaller than this amount may be checking account overdrafts that might best be viewed as a deposit or payments service, and are not likely to be indicative of whether large, foreign-owned, or distressed banks face barriers in providing relationship lending services to informationally opaque small businesses. It is also possible that some of these very small loans are actually personal loans to the owners of the firms, rather than conventional small business loans. 


\section{IV.b. Equations for Testing the Main Hypotheses}

To test whether large banks, foreign-owned, and distressed banks face barriers in relationship lending to informationally opaque small businesses, we run logit equations of the form:

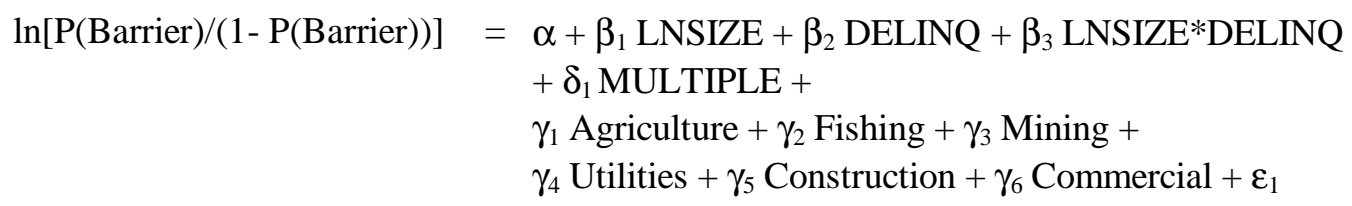

All of the variables in equation (1) are described in Table 1, except for the random error term $\varepsilon_{1}$. The dependent variables are based on BNKASSET10\%, FOREIGN, FOREIGN-SA, FOREIGN-NSA, BNKNPL10\%, BNKLEV10\%, BNKROE10\%, dummies that take on the value 1 if the firm has at least one loan from a bank that faces a potential barrier - one that is large, foreign-owned, or in distress. To ensure robustness, we include a number of different measures of the foreign-owned and distressed-bank barriers. We also run a number of other specifications, including models in which the presence of other barriers are included as control variables. These control for the statistical associations between the dependent variables, which are likely to be strong in some cases (e.g., foreign-owned banks are likely to be large). We acknowledge that these variables are endogenous and their parameters cannot be identified, but we include them only to test robustness.

The most important variables on the right-hand-side of equation (1) are the Firm Opacity/Relationship Strength variables, LNSIZE, DELINQ, and MULTIPLE. Under the main hypotheses, the firms that are most informationally opaque and have the strongest banking relationships are the least likely to be financed by large, foreign-owned, or distressed banks. The first variable is the size of the firm, as indicated by the log of its total bank loans, LNSIZE. Borrower size is an inverse measure of informational opacity because smaller firms typically have less informative financial statements, less experience, and lower public profiles. Under our main hypotheses, smaller firms are less likely to receive loans from large, foreign-owned, or distressed banks. As acknowledged above, firm size may also represent many other firm characteristics as well.

The variable DELINQ measures the proportion of the firm's loans that are at least 60 days past due. This is not by itself a measure of opacity. However, we argue that delinquency likely exacerbates 
opacity problems of small firms and may increase the need for relationship lending services. That is, a delinquent small borrower may be more likely to need the superior informational efficiency associated with a single relationship lender to overcome its difficulties. To capture this effect, we include the interaction term LNSIZE*DELINQ, with the prediction that its coefficient $\beta_{3}$ will be negative under the barriers hypotheses. That is, firm delinquency is likely to exacerbate opacity problems more for smaller firms, since opacity problems are worse for smaller firms. We run the model with and without DELINQ and LNSIZE*DELINQ because we consider these arguments more speculative than those about LNSIZE being an inverse measure of opacity.

Our final Opacity/Relationship variable is MULTIPLE, the indicator for whether the firm has loans from multiple banks. Borrowing from multiple banks may be viewed as an inverse measure of relationship strength and has been used in this capacity in a limited amount of prior research (e.g., Ferri and Messori 2000, Machauer and Weber 2000). Relationships are strongest when they are exclusive, and so this variable may be a good indicator that the firm is not receiving relationship loans based on private information gathered through exclusive contact over time.15 Under our main hypotheses, firms with loans from a single bank are predicted to be less likely to receive loans from large, foreign-owned, or distressed banks.

We run the models with and without the variable MULTIPLE because it is likely endogenous determined simultaneously with whether the firm receives a loan from a barriered bank. Unfortunately, we do not have any instruments to identify its parameter.16 Nonetheless, we believe it is of use to show the results both including and excluding this variable to see its (imperfectly) measured effect and whether the other results are robust to including this variable.

15 Other measures of relationship strength used in empirical research include 1) the existence of a relationship (e.g., Cole 1998), 2) the temporal length of the relationship (e.g., Petersen and Rajan 1994, 1995, Berger and Udell 1995, Angelini, Di Salvo and Ferri 1998, Scott and Dunkelberg 1999), 3) the breadth of a relationship (e.g., Cole 1998, Scott and Dunkelberg 1999, Degryse and Van Cayseele 2000), 4) the degree of mutual trust between the bank and the firm (e.g., Harhoff and Körting 1998a), 5) the number of different account managers (e.g., Scott and Dunkelberg 1999), and 6) the presence of a hausbank or main bank (Elsas and Krahnen 1998).

16 Our tests of the secondary hypotheses shown below do include potential instruments - variables that are in equation (2) with MULTIPLE as the dependent variable that are excluded from equation (1). However, these are measures of whether the primary lender is large, foreign-owned, and distressed, which are not exogenous to whether the firm has one or more loans from a bank with one of these characteristics. 
Thus, under the Bank Barriers Hypotheses, there are three predictions from each equation. First, there should be a positive effect of LNSIZE, as smaller firms are more opaque and less likely to borrow from barriered banks. When DELINQ and LNSIZE*DELINQ are excluded from the model, the derivative of the dependent variable in (1) with respect to LNSIZE is $\beta_{1}$. When the extra terms are included, this derivative becomes $\beta_{1}+\beta_{3}$ DELINQ. Second, there should be a negative effect of the interaction term LNSIZE*DELINQ $\left(\beta_{3}<0\right)$ under the barriers hypotheses, as firm delinquency is likely to exacerbate opacity problems more for smaller firms. Third, the hypotheses predict a positive effect of MULTIPLE when it is included - firms with single banking relationships are likely to be more opaque and relationship-dependent, and therefore less likely to borrow from barriered banks. We also include variables for industry category for purposes of statistical control. We offer no predictions regarding these variables because we have no strong reason to expect that any of these general categories may be more or less opaque than the others.

Our main hypotheses are intended to apply principally to informationally opaque small businesses, rather than large firms, and we ignore a number of reasons why large firms may or may not receive loans from large, foreign-owned, or distressed banks. For example, large firms often tend to borrow from large banks mostly because small banks may face funding constraints, diversification problems, and supervisory/regulatory resistance to exposing too much of their capital to a single borrower, including legal lending limits in Argentina. As well, small banks may not be able to deliver other capital market products needed by large firms, such as complex financial derivatives. Some large firms may choose to borrow from foreign-owned banks because these firms or their corporate affiliates have already established ties to these banking organizations in other countries.

We run our models separately for the smallest $25 \%$ of firms, smallest $50 \%$ of firms, as well as for all firms. This allows us to avoid confounding our main hypotheses about the barriers faced by large, foreign-owned, or distressed banks in making loans to small, informationally opaque firms with the reasons why small, domestic, healthy banks tend not to make loans to very large firms. Presumably, almost all healthy banks can easily make loans to customers with debt as high as 10,000 pesos or 33,600 pesos, the cutoffs for our smallest $25 \%$ and $50 \%$ of firms, respectively. Running the model by size group also allows us to see how the marginal effects of informational opacity vary for different sizes of 
firms, and for which firm sizes the main hypotheses are consistent with the data.

\section{IV.c. Equations for Testing the Secondary Hypotheses}

To test our secondary hypotheses about the conditions that result in a firm borrowing from a single bank versus borrowing from multiple banks, we run logit equations of the form:

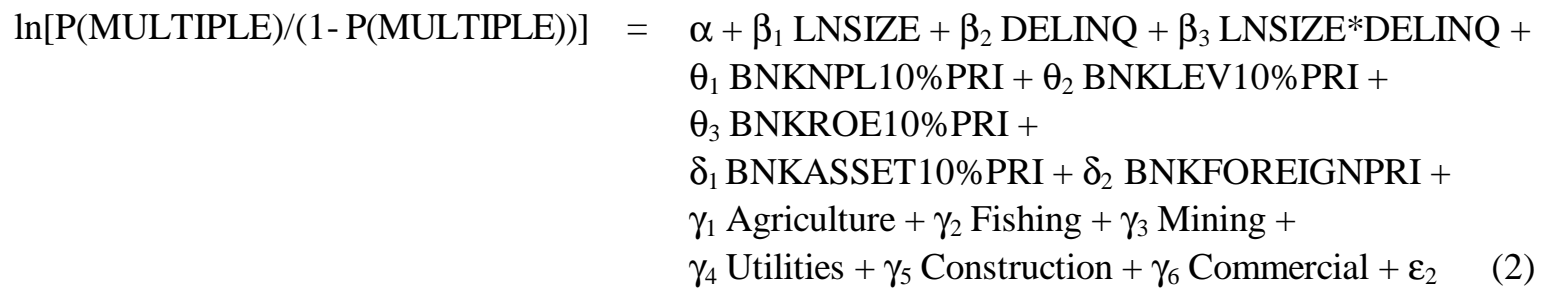

The variables in equation (2) are described in Table 2, except for the random error term $\varepsilon_{2}$. The dependent variable is based on a dummy that the firm has loans outstanding from multiple banks. We run the models for the smallest $25 \%$ of firms, smallest $50 \%$, and all firms to avoid confounding our hypotheses with alternative explanations of the data for large firms.17 This also allows us to measure how borrower opacity and primary bank distress vary for different sizes of firms and to see for which firm sizes the secondary hypotheses are most consistent with the data. To ensure that the test results are robust, we run the models with several different exclusion restrictions discussed below.

The key exogenous variables are the Firm Opacity variables and the measures of primary bank distress. The Firm Opacity variables include LNSIZE, DELINQ, and the interaction term. We measure whether the firm's primary bank is in distress with three dummy variables - BNKNPL10\%PRI, BNKLEV10\%PRI, and BNKROE10\%PRI - that measure whether it is in the worst $10 \%$ of banks in terms of its nonperforming loans, leverage, and earnings. As shown in Table 2, we also have controls for whether the firm's primary bank is large or foreign-owned - BNKASSET10\%PRI and FOREIGNPRIas well as the controls for the firm's industry.

17 Very large firms tend to borrow from multiple banks because even a large single bank may be constrained in risking too much of their capital in loans to a single very large borrower. Some nationwide or multinational large firms may also borrow from multiple banks to facilitate their operations in different regions or nations. Other factors about the nation's financial markets may also affect the single-bank-versus-multiple-bank outcome, including the enforceability of creditor rights, fragmentation of the banking system, and the existence of an active bond market (Detragiache, Garella, and Guiso 2000, Ongena and Smith 2000). 
The important predictions from equation (2) are as follows. If the Multiple-Bank Bank-Distress Hypothesis is true, we expect positive effects of primary bank distress $\left(\theta_{1}, \theta_{2}, \theta_{3}>0\right)$, as firms borrow from extra banks to protect themselves against the potential cutoff of credit or other deterioration of credit terms from distressed primary banks. The hypotheses yield opposing predictions for the opacity variables, so we look for the net effect of which hypothesis dominates. If the Single-Bank Firm-Opacity Hypothesis dominates, we expect a negative effect of opacity $\left(\beta_{1}>0, \beta_{3}<0\right)$, because smaller, more opaque firms are likely to derive greater net benefits from a single banking relationship. If the MultipleBank Bank-Distress Hypothesis dominates, these signs are reversed because more opaque firms need greater protection against the potential cutoff of credit.

\section{Empirical Results}

Tables 3-9 show our tests of our main hypotheses - the Large-Bank, Foreign-Owned-Bank, and Distressed-Bank Barriers Hypotheses. As discussed earlier, we run our models separately for the smallest $25 \%$ of firms, smallest $50 \%$ of firms, and all firms to avoid confounding our main hypotheses about the barriers in lending to small, informationally opaque firms with reasons why other banks tend not to make loans to large firms, and to see how the results vary for different sizes of firms. The hypotheses are mainly intended to apply to the smaller size groups.

For each firm size group, we run each model three times, once with LNSIZE as the only indicator of Firm Opacity/Relationship Strength, once with DELINQ and LNSIZE*DELINQ included as well, and once with MULTIPLE also included. Under the Bank Barriers Hypotheses, the predictions are a positive effect of LNSIZE (smaller firms are less likely to borrow from barriered banks), a negative effect of the interaction term LNSIZE*DELINQ (firm delinquency is likely to exacerbate opacity problems more for smaller firms), and a positive effect of MULTIPLE (firms with single banking relationships are more opaque and less likely to borrow from barriered banks).

The tests of the Large-Bank Barriers Hypothesis are shown in Table 3. The simplest model in which LNSIZE is the sole Opacity/Relationship indicator is shown in columns (1), (4), and (7) of the table for the smallest $25 \%$ of firms, smallest $50 \%$, and all firms, respectively. The coefficients of LNSIZE in these columns are all positive and statistically significant at the $1 \%$ level. These are consistent with the prediction of the hypothesis that within each size group, a smaller firm is more 
opaque and therefore is less likely to have a loan from a large bank.

We evaluate the economic significance of firm size by simulating the effect of doubling firm size and calculating the change in the probability of receiving a loan from a barriered bank, starting from the subsample means for $\mathrm{P}($ Bank Barrier) and all the other variables. For the smallest $25 \%$ of firms in column (1), the probability of receiving a loan from a large bank increases from $54.55 \%$ to $63.73 \%$. This amounts to an economically significant $16.83 \%$ increase in the probability of receiving a loan from a large bank, which is displayed in a row near the bottom of the table. For the smallest $50 \%$ of firms and for all firms in columns (4) and (7), respectively, the probability of receiving a loan from a large bank is predicted to increase by only about $6 \%$ as firm size doubles. As discussed above, we expect greater effects for differences in opacity among smaller firms under the Large-Bank Barriers Hypothesis.

We next examine the effects of LNSIZE in the other models shown in Table 3 with additional Opacity/Relationship indicators included. In these models, the economic significance depends upon both the coefficients of LNSIZE and the interaction term LNSIZE*DELINQ. As shown in the table, the inclusion of DELINQ and LNSIZE*DELINQ makes virtually no difference to the economic significance of LNSIZE. The results in columns (2), (5), and (8) again suggest that as the size of the firm doubles, the probability of receiving a loan from a large bank is predicted to increase by about $17 \%$ for the smallest $25 \%$ of firms and by about $6 \%$ for the smallest $50 \%$ of firms and for all firms. The inclusion of MULTIPLE has virtually no effect on the economic significance of LNSIZE for the smallest $25 \%$ of firms, as shown in column (3). However, the inclusion of MULTIPLE eliminates most of the economic significance of LNSIZE for the smallest $50 \%$ of firms and for all firms - reducing the effect of doubling firm size on the probability of borrowing from a large bank to less than $2 \%$. This may suggest that for larger firms, having loans from multiple banks is an overwhelming inverse indicator of relationship strength that dominates changes in firm size. The fact that the effects of LNSIZE are more robust for the smallest $25 \%$ of firms again is consistent with the predictions of the Large-Bank Barriers Hypothesis, which applies principally to the smallest firms.

We next examine the coefficients of the interaction term LNSIZE*DELINQ in the models that include this term in Table 3 . We find that the coefficients on these interaction terms are all negative and 5 of the 6 coefficients are statistically significant at the $1 \%$ level and the remaining coefficient is 
significant at the $10 \%$ level. These negative coefficients are consistent with the hypothesis - firm delinquency may exacerbate opacity problems more for smaller firms within each of our size groups. The coefficients are more than twice as large in absolute value for the smallest $25 \%$ of firms than for the smallest 50\% of firms and all-firms models, consistent with the Large-Bank Barriers Hypothesis.

The coefficients of MULTIPLE are positive and statistically significant at the $1 \%$ level for all 3 size groups. These are consistent with the prediction of the hypothesis that firms with single banking relationships are more informationally opaque and less likely to borrow from large banks. We evaluate the economic significance of MULTIPLE by simulating switching from a single bank to multiple banks and calculating the change in the probability of receiving a loan from a barriered bank, starting from the subsample means for all the other variables. As shown near the bottom of Table 3, the probability of receiving a loan from a large bank is predicted to increase substantially as the firm switches from a single bank to multiple banks, more than doubling (increasing by more than 100\%) for the two smallest size groups. The effect is greatest for the smallest $25 \%$ of firms, consistent with the hypothesis. As discussed above, the variable MULTIPLE is likely endogenous, and we do not have any instruments for it, but we show the results both including and excluding this variable to see its (imperfectly) measured effect and to test the robustness of the other results.

We conduct other robustness checks as well. We rerun the tests of the barriers hypotheses including the presence of other barriers as control variables, despite their endogeneity. Although these models are not fully identified, the purpose is to control for the statistical associations among the barrier indicator variables and to be sure that one barrier variable is not proxying for another barrier. In testing the Large-Bank Barriers Hypothesis, a particular concern is that BNKASSET10\% may in part be picking up the effects of the Foreign-Owned-Bank Barriers Hypothesis, since most of the largest banks are also foreign-owned.18 As well, at the time of our sample in 1998, the largest banks generally had less financial distress than other institutions, raising a concern that BNKASSET10\% may in part proxy

18 The variable BNKASSET10\% equals 1 if the firm borrows from any of the 10 largest privately owned banks in Argentina, and 8 of these 10 banks are also foreign owned. However, the largest two banks in the country are both domestically owned. Banco de la Nacion Argentina and Banco de la Provincia de Buenos Aires together account for more than $20 \%$ of the lending in the nation. 
(inversely) for the effect of the Distressed-Bank Barriers Hypothesis. When we include the FOREIGN and BNKNPL10\% dummies on the right-hand-side, the test results were materially unchanged (not shown in tables).

In sum, the results are generally consistent with the Large-Bank Barriers Hypothesis. For the smallest $25 \%$ of firms, the coefficients of LNSIZE, LNSIZE*DELINQ, and MULTIPLE are all of the predicted sign and statistically significant at the $1 \%$ level, the measured effects of LNSIZE and MULTIPLE are economically significant, and these findings are robust to inclusion or exclusion of some of the Opacity/Relationship indicators and indicators of the other barriers as control variables. The statistical and economic significance were somewhat less when the models included data for the smallest $50 \%$ of firms and all firms, but as noted above, the Large-Bank Barriers Hypothesis applies principally to the smallest firms, and these are the cleanest tests in terms of avoiding competing hypotheses about lending to large firms.

The tests of the Foreign-Owned-Bank Barriers Hypothesis are shown in Tables 4, 5, and 6, which display the findings for all foreign-owned banks, those headquartered in other South American nations, and those headquartered in non-South American countries, respectively. Looking first at Table 4 for all foreign-owned banks, the measured effects of LNSIZE are generally consistent with the hypothesis - within each size group, a smaller firm appears to be less likely to have a loan from a foreign-owned institution. The coefficients of LNSIZE are all positive and statistically significant at the $1 \%$ level in columns (1), (4), and (7), and doubling firm size generally increases the predicted probability of borrowing from foreign banks by about $10 \%$ in most cases. Similar to the tests in Table 3 above, the inclusion of MULTIPLE substantially reduces the measured effects of LNSIZE for the smallest $50 \%$ and all-firms size groups. Also similar to the earlier tests, the coefficients of the interaction term LNSIZE*DELINQ are all negative and statistically significant, and the measured effects of MULTIPLE are positive and both economically and statistically significant. As well, all of the measured effects are at least somewhat stronger for the subsample of the smallest $25 \%$ of firms than for the subsample of the smallest $50 \%$ of firms and for the full sample of all firms.

Thus, the results in Table 4 are qualitatively similar to those in Table 3 and are generally consistent with the Foreign-Owned-Bank Barriers Hypothesis. However, not all of the results are 
robust to the inclusion of the presence of other barriers as control variables. Specifically, the effects of LNSIZE become economically and statistically insignificant and the interaction term, LNSIZE*DELINQ, becomes statistically insignificant for the smallest $25 \%$ of firms when BNKASSET10\% and BNKNPL10\% are included as control variables. However, the results for the smallest $50 \%$ and all-firms models remained robust to the inclusion of these variables. One reason why the measured effect of LNSIZE on the probability of borrowing from a foreign-owned bank may disappear when large bank size is controlled for is that foreign banks that are not large simply make so few loans to the smallest $25 \%$ of firms - only $7.6 \%$ of these firms have loans from foreign-owned banks that are not in the top $10 \%$ in terms of bank assets. That is, after taking account of the strong effect of large bank size, there may simply be too little variation in the FOREIGN variable for small firms. In sum, most of the results are consistent with the Foreign-Owned-Bank Barriers Hypothesis, but it is much less certain that the hypothesis predicts the marginal effects of firm size within the smallest $25 \%$ of firms size group.

The results shown in Table 5 for the foreign-owned banks headquartered in other South American nations are generally less statistically and economically significant than for all the foreign banks shown in Table 4. The results suggest a generally weaker correspondence with the ForeignOwned-Bank Barriers Hypothesis for foreign-owned banks headquartered on the same continent, with the effect of LNSIZE being statistically insignificant for the smallest $25 \%$ of firms, and the coefficients of LNSIZE*DELINQ being positive for the smallest $25 \%$ and smallest $50 \%$ of firms. In contrast, the results shown in Table 6 for the foreign banks headquartered in non-South American countries are quite similar to those for all foreign-owned banks.19 The findings in these tables generally suggest that any barriers to foreign-owned banks making relationship-based loans to informationally opaque small businesses are likely to be greater for banks based outside of South America, perhaps due to longer distances, or greater differences in language, culture, supervisory/regulatory structures, and so forth.

The tests of the Distressed-Bank Barriers Hypothesis are shown in Tables 7, 8, and 9, which

19 As occurred for the main sample, the effects of LNSIZE and LNSIZE*DELINQ become statistically insignificant for the smallest 25\% of firms when BNKASSET10\% and BNKNPL10\% are included as control variables. The similarity of results in Tables 4 and 6 is not surprising, since the banks headquartered in non-South American countries are generally quite large and account for most of the lending by foreign-owned banks. 
give the findings for banks with nonperforming loan problems, leverage problems, and earnings problems, respectively. The data generally do not support the Distressed-Bank Barriers Hypothesis. The coefficients on LNSIZE and the interaction term LNSIZE*DELINQ are often insignificant or of inconsistent signs - in many cases distressed banks appear to favor smaller, more delinquent firms. As discussed above, the effects of bank distress may in some cases be concentrated more on large firms that receive transactions loans because banks may wish to protect future rents by keeping their relationship borrowers or because large firms may more easily switch to healthy banks when their banks become distressed. Generally, we cannot conclude whether the effect of bank distress on lending to small opaque borrowers is greater than or less than the effect on lending to large, transparent borrowers.

Table 10 shows the tests of our secondary hypotheses - the Single-Bank Firm-Opacity and Multiple-Bank Bank-Distress Hypotheses. The equations are estimated using logit discrete choice models, and the dependent variable in each case is a dummy for whether the firm has loans outstanding from multiple banks. We run the models for the smallest $25 \%$ of firms, smallest $50 \%$, and all firms for the reasons discussed above.

For each size group, we show three regressions, one with just LNSIZE and the control variables, one that adds in the DELINQ and LNSIZE*DELINQ terms, and one that also includes the primary bank distress variables. As indicated earlier, if the Single-Bank Firm-Opacity Hypothesis is dominant, we expect a positive effect of LNSIZE (smaller firms have greater net benefits from a single banking relationship), a negative effect of the interaction term LNSIZE*DELINQ (firm delinquency is likely to exacerbate opacity problems more for smaller firms), while these signs are reversed if the Multiple-Bank Bank-Distress Hypothesis is dominant (more opaque firms need more protection against the potential cutoff of credit). Under the Multiple-Bank Bank-Distress Hypothesis, we also expect positive effects of the indicators of primary bank distress (firms with distressed primary banks seek protection against the potential cutoff of credit).

The clearest results in Table 10 are shown in the full specifications of the model in columns (3), (6), and (9). In these columns, the coefficients of the indicators of primary bank distress BNKNPL10\%PRI, BNKLEV10\%PRI, and BNKROE10\%PRI - are all positive and are almost all statistically significant, consistent with firms seeking protection from the potential cutoff of credit under 
the Multiple-Bank Bank-Distress Hypothesis. The results are generally stronger for the smallest 25\% and smallest $50 \%$ of firms, which may reflect that these banks might have the greatest cost from having their credit cut off by a distressed or failed primary bank.

The coefficients of LNSIZE are positive and statistically significant at the $1 \%$ level in all cases, and the predicted effects of doubling firm size are also positive and economically significant. This finding is consistent with a dominance of the Single-Bank Firm-Opacity Hypothesis, under which a smaller firm within each size group is more likely to need the relationship lending services of a single bank. However, the findings for the interaction term LNSIZE*DELINQ are not as clear. These coefficients are positive and statistically significant for the smallest $25 \%$ of firms, but negative and much smaller in magnitude for the smallest 50\% and all-firms groups. One possible interpretation is for the smallest $25 \%$ of firms, the positive, significant coefficients reflect a domination of the Multiple-Bank Bank-Distress Hypothesis for the effects of delinquency for this group. That is, the small firms that have their own repayment problems are the most worried about being cut off from a distressed bank and therefore seek multiple lenders if they can obtain them. However, the change in sign for larger firms and the dominance of the Single-Bank Firm-Opacity Hypothesis in the measured effects of LNSIZE make it difficult to draw strong conclusions from the interaction terms.

\section{Conclusion}

The consolidation of the banking industry is shifting assets into larger institutions that often operate in many nations. Given the orientation of most large, international organizations toward serving large, wholesale customers, consolidation raises the issue of the ability of the banking system to supply credit to informationally opaque small businesses in the future. Bank financial distress may also create problems of credit availability for these firms, as evidenced by the financial crises and credit crunches around the globe in recent years.

To shed light on these issues, we test several hypotheses about the supply of relationship credit to informationally opaque small businesses. Under the Large-Bank Barriers Hypothesis, ForeignOwned-Bank Barriers Hypothesis, and Distressed-Bank Barriers Hypothesis, large bank size, foreign ownership, and bank distress, respectively, represent significant barriers to providing relationship lending services. We use a rich, new data set to test these hypotheses that matches information on 
individual small businesses, their bank loans, and their banks.

The data are generally consistent with the Large-Bank Barriers Hypothesis and the ForeignOwned-Bank Barriers Hypothesis, although the latter hypothesis may only be effective if the foreign bank is headquartered in a far-away nation. Informationally opaque small businesses tend to receive less credit from large banks and foreign banks, and this effect is magnified for small businesses with delinquencies in repaying their loans. The data do not support the Distressed-Bank Barriers Hypothesis - the effect of bank distress on lending does not appear to be consistently any stronger for informationally opaque small businesses than for large transactions borrowers.

We also test some related secondary hypotheses regarding which firms borrow from a single bank versus from multiple banks. Under the Single-Bank Firm-Opacity Hypothesis, informationally opaque small businesses are more likely to have a single lender than other firms. This is because for these businesses, the benefits associated with the acquisition and possession of proprietary information by a single lender likely outweighs the potential costs of exploitation of market power in an exclusive relationship. Under the Multiple-Bank Bank-Distress Hypothesis, the single-versus-multiple-bank decision depends on the financial condition of the firm's primary bank - firms borrow from multiple lenders to insure their own credit availability if their primary bank is in financial distress. The data support the Multiple-Bank Bank-Distress Hypothesis - firms tend to borrow from multiple banks when their primary bank is in financial distress. The data also suggest that smaller firms tend to have exclusive lending relationships, all else equal, providing some limited support for the Single-Bank FirmOpacity Hypothesis.

There are many policy concerns regarding bank mergers and acquisitions (M\&As), foreign entry, and prudential supervision and regulation, and this research focuses on one of these concerns - the supply of relationship credit to informationally opaque small businesses. Our results suggest that some large and foreign-owned institutions that are created by M\&As and foreign entry may have difficulty extending relationship loans to opaque small firms. Any bank distress that may result from lax prudential supervision and regulation appears to have no greater effect on the supply of credit to small borrowers than to large borrowers. However, even some small firms may react to bank distress by borrowing from multiple banks, creating additional real resource costs as well as the destruction of some 
of the benefits from relationship lending. Our results and those in the related literature are subject to a number of important caveats. The overall supply of relationship credit to opaque small firms depends on many other factors as well, including i) whether other banks in the market or new entrants compensate by changing their supply of relationship credit, ii) the robustness of the empirical results, and iii) how well the results apply across nations with different market environments. 


\section{$\underline{\text { References }}$}

Angelini, P., Salvo, R.D., Ferri, G., 1998. Availability and cost for small businesses: Customer relationships and credit cooperatives, Journal of Banking and Finance, 22, 929-954.

Avery, R.B., Samolyk, K.A. 2000. Bank consolidation and the provision of banking services: The case of small commercial loans, Federal Deposit Insurance Corporation working Paper.

Berger, A.N., Bonime, S.D., Goldberg, L.G., White, L.J., 2000. The dynamics of market entry: The effects of mergers and acquisitions on entry in the banking industry, Federal Reserve Board working paper.

Berger, A.N., Goldberg, L.G., White, L.J., 2001. The effects of dynamic changes in bank competition on the supply of small business credit, European Finance Review.

Berger, A.N., DeYoung, R., 2001. The effects of geographic expansion on bank efficiency, Journal of Financial Services Research 19.

Berger, A.N., DeYoung, R., Genay, H., Udell, G.F., 2000. Globalization of financial institutions: Evidence from cross-border banking performance, Brookings-Wharton Papers on Financial Services, 3, 23-158.

Berger, A.N., Kashyap, A.K, Scalise, J.M., 1995. The transformation of the U.S. banking industry: What a long, strange trip it's been, Brookings Papers on Economic Activity, 2, 55-218.

Berger, A.N., Kyle, M.K., Scalise, J.M., forthcoming. Did U.S. bank supervisors get tougher during the credit crunch? Did they get easier during the banking boom? Did it matter to bank lending? In F.S. Mishkin, ed., Prudential Supervision: What Works and What Doesn't, National Bureau of Economic Research, University of Chicago Press (Chicago, IL).

Berger, A.N., Rosen, R.J., Udell, G.F., 2001. The effect of banking market size structure on bank competition: The case of small business lending, Federal Reserve Board working paper, Washington, DC.

Berger, A.N., Saunders, A., Scalise, J.M., Udell, G.F., 1998. The effects of bank mergers and acquisitions on small business lending, Journal of Financial Economics, 50(2): 187-229.

Berger, A.N., Udell, G.F., 1994. Did risk-based capital allocate bank credit and cause a 'credit crunch' in the United States? Journal of Money, Credit, and Banking 26 (August), 585-628.

Berger, A.N., Udell, G.F., 1995. Relationship lending and lines of credit in small firm finance, Journal of Business, 68, 351-382.

Berger, A.N., Udell, G.F., 1996. Universal banking and the future of small business lending, edited by A. Saunders and I. Walter, Financial system design: The case for universal banking, Burr Ridge, IL, Irwin Publishing, 559-627.

Berger, A.N., Udell, G.F., 1998. The economics of small business finance: The roles of private equity and debt markets in the financial growth cycle, Journal of Banking and Finance, 22, 613-74. 
Berlin, M., Mester, L.J., 1998. On the profitability and cost of relationship lending, Journal of Banking and Finance, 22, 873-897.

Bhattacharya, S., Chiesa, G., 1995. Proprietary information, financial intermediation, and research incentives, Journal of Financial Intermediation, 4, 328-357.

Black, S.E., Strahan, P.E., 2000. Entrepreneurship and bank credit availability, Federal Reserve Bank of New York working paper.

Blackwell, D., Winters, D.B., 1997. Banking relationships and the effect of monitoring on loan pricing, Journal of Financial Research 20, 275-89.

Boot, A.W.A, 2000. Relationship banking: What do we know?, Journal of Financial Intermediation, 9 , $7-25$.

Boot, A.W.A., A.V. Thakor, 1994, Moral hazard and secured lending in an infinitely repeated credit market game, International Economic Review, 35, 899-920.

Bonaccorsi di Patti, E., Dell'Ariccia, G. 2001. Bank competition and firm creation, International Monetary Fund working paper 01/21.

Bonaccorsi di Patti, E., Gobbi, G. 2000. The effects of bank consolidation on small business lending: Evidence from market and firm data, Bank of Italy working paper.

Calomiris, C., Powell, A., 2000. Can emerging market bank regulators establish credible discipline? The case of Argentina, 1992-1999, working paper.

Caprio, G. Jr., Klingebiel, D., 1996. Bank insolvencies: Cross-country experience, World Bank Policy Research Working Paper 1620.

Carey, M., Prowse, S, Rea, J., Udell, G., 1993. The Economics of the Private Placement Market, Financial Markets, Institutions \& Instruments 2.

Carey, M., Post, M., Sharpe, S.A., 1998. Does corporate lending by banks and finance companies differ? Evidence on specialization in private debt contracting, Journal of Finance, 53, 845-878.

Chiou, I., 1999. Daiwa Bank's reputational crisis: Valuation effects on bank-firm relationships, New York University working paper.

Claessens, S., Demirgüc-Kunt, A., Huizinga, H., 2001. How does foreign entry affect the domestic banking market? Journal of Banking and Finance, 25, 891-911.

Claessens, S., Djankov, S., Ferri, G., 1999. Corporate distress in East Asia: The effect of currency and interest rate shocks, World Bank working paper.

Clarke, G., Cull, R., 1998. The political economy of privatization: The case of Argentina's public provincial banks, World Bank Policy Research Working Paper \# 1962.

Clarke, G., Cull, R., D’Amato, L., Molinari, A., 1999. On the kindness of strangers? The impact of foreign entry on domestic banks in Argentina, World Bank working paper. 
Cole, R.A., 1998. The importance of relationships to the availability of credit, Journal of Banking and Finance, 22, 959-77.

Cole, R.A., Goldberg, L.G., White, L.J., 1999. Cookie-cutter versus character: The micro structure of small business lending by large and small banks, in Business Access to Capital and Credit, edited by J.L. Blanton, A. Williams, and S.L.W. Rhine, A Federal Reserve System Research Conference, 362-389.

Cole, R.A., Walraven, N., 1998. Banking consolidation and the availability of credit to small business, Federal Reserve Board working paper.

Cull, R., 1998. Structural change: Internationalization, consolidation, and privatization in Argentina's banking sector, 12/94-9/97, World Bank working paper.

Cyrnak, A., Hannan, T.H. 2000. "Non-local lending to small businesses." Federal Reserve Board working paper.

Dell'Ariccia, G., Marquez R., 2001. Flight to quality or to captivity? Information and credit allocation, International Monetary Fund working paper 01/20.

DeYoung, R., Nolle, D.E., 1996. Foreign-owned banks in the U.S.: Earning market share or buying it? Journal of Money, Credit, and Banking 28(4): 622-636.

Degryse, H., Cayseele, P.V., 2000. Relationship lending within a bank-based system: Evidence from European small business data, Journal of Financial Intermediation, 9, 90-109.

Demirgüc-Kunt, A., Detragiache, E., Gupta, P., 2000. Inside the crisis: An empirical analysis of banking systems in distress, World Bank working paper.

Detragiache, E, Garella, P.G., Guiso, L., 2000. Multiple versus single banking relationships: Theory and evidence, Journal of Finance, 55, 1133-1161.

Diamond, D.W., 1984, Financial intermediation and delegated monitoring, Review of Economic Studies, 51, 393-414.

Djankov, S., Jindra, J., Klapper, L., 1999. Corporate valuation and the resolution of bank insolvency in East Asia, World Bank working paper.

Farinha, L.A., Santos, J.A.C., 2000. Switching from single to multiple banking relationships: Determinants and implications, Bank for International Settlements working paper.

Ferri, G., Messori, M., 2000. Bank-firm relationships and allocative efficiency in northeastern and central Italy and in the South, Journal of Banking and Finance 24: 1067-1095.

Goldberg, L., Dages, B.G., Kinney, D., 2000. Foreign and domestic bank participation in emerging markets: Lessons from Mexico and Argentina, Federal Reserve Bank of NY working paper.

Grosse, R., Goldberg, L.G., 1991. Foreign bank activity in the United States: An analysis by country of origin, Journal of Banking and Finance 15: 1093-1112. 
Grinblatt, M., Keloharju, M., 2001. How distance, language, and culture influence stockholdings and trades, Journal of Finance 56, 1053-1073.

Hancock, D., Laing, A., Wilcox, J., 1995. Bank balance sheet shocks and aggregate shocks: Their dynamic effects on bank capital and lending, Journal of Banking and Finance, 19: 661-77.

Hancock, D., Wilcox, J.A., 1998. The 'credit crunch' and the availability of credit to small business, Journal of Banking and Finance 22, 983-1014.

Harhoff, D., Körting, T., 1998. Lending relationships in Germany: Empirical results from survey data, Journal of Banking and Finance 22, 1317-1354.

Hauswald, R., Marquez, R., 2000. Relationship banking, loan specialization and competition, Indiana University working paper.

Haynes, G.W., Ou, C., Berney, R., 1999. Small business borrowing from large and small banks, in Business Access to Capital and Credit, edited by J.L. Blanton, A. Williams, and S.L.W. Rhine, A Federal Reserve System Research Conference, 287-327.

Jayaratne, J., Wolken, J.D., 1999. How important are small banks to small business lending? New evidence from a survey to small businesses, Journal of Banking and Finance, 23: 427-458.

Kang, J.-K., Stulz, R., 2000. Do banking shocks affect borrowing firm performance? An analysis of the Japanese experience, Journal of Business, V73, n1, 1-23.

Karceski, J., Ongena, S., Smith, D., 2000. The impact of bank consolidation on the welfare and behavior of customers, Federal Reserve Board working paper.

Keeton, W.R., 1995. Multi-office bank lending to small businesses: Some new evidence, Federal Reserve Bank of Kansas City Economic Review, 80 (2), 45-57.

Keeton, W.R., 1996. Do bank mergers reduce lending to businesses and farmers? New evidence from tenth district states, Federal Reserve Bank of Kansas City Economic Review, 81: 63-75.

Levine, R., 1996. Foreign banks, financial development, and economic growth, in Claude E. Barfield, ed., International Financial Markets: Harmonization Versus Competition, Washington DC: The AEI Press.

Longhofer, S.D., Santos, J.A.C., 2000. The importance of bank seniority for relationship lending, Journal of Financial Intermediation, 9, 57-89.

Machauer, A., Weber, M., 2000. Number of bank relationships: An indicator of competition, borrower quality, or just size?, University of Mannheim working paper.

Martinez Peria, M.S., Schmukler, S.S., 2001. Do depositors punish banks for bad behavior? Market discipline, deposit insurance and banking crises, Journal of Finance, 56.

Ongena, S., Smith, D.C., 2000. What determines the number of bank relationships? Journal of Financial Intermediation, 9, 26-56. 
Ongena, S., Smith, D., Michalsen, D., 2000. Firms and their distressed banks: Lessons from the Norwegian Banking Crisis (1988-1991), Federal Reserve Board working paper.

Peek, J., Rosengren, E.S., 1995. Bank regulation and the credit crunch, Journal of Banking and Finance, 19: 679-92 (a).

Peek, J., Rosengren, E.S., 1995. The capital crunch: Neither a borrower nor a lender be, Journal of Money, Credit and Banking, 27: 625-38 (b).

Peek, J., Rosengren, E.S., 1996. Small business credit availability: How important is size of lender?, edited by A. Saunders and I. Walter, Financial System Design: The Case for Universal Banking, Burr Ridge, IL, Irwin Publishing, 628-55.

Peek, J., Rosengren, E.S., 1998. Bank consolidation and small business lending: It's not just bank size that matters, Journal of Banking and Finance, 22, 799-819.

Peek, Joe, Rosengren, E.S., Kasirye, F., 1999. The poor performance of foreign bank subsidiaries: Were the problems acquired or created? Journal of Banking and Finance 23: 579-604.

Petersen, M.A., Rajan, R.G., 1994. The benefits of firm-creditor relationships: Evidence from small business data, Journal of Finance, 49, 3-37.

Petersen, M.A., Rajan, R.G., 1995. The effect of credit market competition on lending relationships, Quarterly Journal of Economics, 110, 407-443.

Petersen, M.A., Rajan, R.G., 2000. Does distance still matter? The information revolution in small business lending, working paper.

Raffin, M., 1999. A note on the profitability of the foreign-owned banks in Argentina, Banco Central de la Republica Argentina, Technical Note Number 6.

Rajan, R.G., 1992. Insiders and outsiders: The choice between informed and arm's-length debt, Journal of Finance, 47, 1367-99.

Scott, J.A., Dunkelberg, W.C., 1999. Bank consolidation and small business lending: A small firm perspective, in Business Access to Capital and Credit, edited by J.L. Blanton, A. Williams, and S.L.W. Rhine, A Federal Reserve System Research Conference, 328-361.

Seelig, S.A., Critchfield, T., 1999. Determinants of de novo entry in banking, Federal Deposit Insurance Corporation Working Paper 99-1.

Sharpe, S.A., 1990. Asymmetric information, bank lending, and implicit contracts: A stylized model of customer relationships, Journal of Finance, 45,1069-87.

Shrieves, R.E., Dahl, D., 1995. Regulation, recession, and bank lending behavior: The 1990 credit crunch, Journal of Financial Services Research, 9: 5-30.

Slovin, M.B., Sushka, M.E., Polonochek, J.A., 1993. The value of bank durability: Borrowers as bank stakeholders, Journal of Finance, 48, 247-66. 
Stanley, T.O., Roger, C., McManis, B., 1993. The effects of foreign ownership of U.S. banks on the availability of loanable funds to small business, Journal of Small Business Management, 31, 51-66.

Stein, J.C., 2001. Information production and capital allocation: Decentralized vs. hierarchical firms, Harvard University working paper.

Strahan, P.E., Weston, J.P., 1996. Small business lending and bank consolidation: Is there cause for concern? Current issues in Economics and Finance 2, Federal Reserve Bank of New York 2, 16.

Strahan, P.E., Weston J.P., 1998. Small business lending and the changing structure of the banking industry, Journal of Banking and Finance, 22, 821-45.

Wagster, J.D. 1999. The Basle Accord of 1988 and the International Credit Crunch of 1989-1992, Journal of Financial Services Research, 15: 123-143.

Whalen, G., 1995. Out-of-state holding company affiliation and small business lending, Office of the Comptroller of the Currency, Economic and Policy Analysis working paper 95-4. 


\section{Table 1: Definitions and Summary Statistics for Variables Used to Test the Main Hypotheses}

Summary statistics are for the sample of firms used to test the Large-Bank, Foreign-Owned Bank and Distressed-Bank Barriers Hypotheses. The total number of observations is 61,295, which excludes all firms whose primary bank is state-owned and firms with total bank loans less than 2,000 pesos.

\begin{tabular}{|c|c|c|c|c|}
\hline Variable Name & & $\underline{\text { Definition }}$ & Mean & $\underline{\text { Std Dev }}$ \\
\hline \multicolumn{5}{|c|}{ Bank Barrier Variables (Dependent Variables) } \\
\hline BNKASSET10\% & $=$ & $\begin{array}{l}1 \text { if a firm borrows from at least one bank that is in the } \\
\text { largest } 10 \% \text { of banks ranked by asset size (excluding state- } \\
\text { owned banks) }\end{array}$ & $65.08 \%$ & $47.67 \%$ \\
\hline FOREIGN & $=$ & 1 if a firm borrows from at least one bank that is foreign & $52.89 \%$ & $49.92 \%$ \\
\hline FOREIGN-SA & $=$ & $\begin{array}{l}1 \text { if a firm borrows from at least one foreign-owned bank } \\
\text { headquartered in a South American country other than } \\
\text { Argentina }\end{array}$ & $10.55 \%$ & $30.71 \%$ \\
\hline FOREIGN-NSA & $=$ & $\begin{array}{l}1 \text { if a firm borrows from at least one foreign-owned bank } \\
\text { NOT headquartered in another South American country }\end{array}$ & $42.35 \%$ & $49.41 \%$ \\
\hline BNKNPL10\% & $=$ & $\begin{array}{l}1 \text { if a firm borrows from at least one bank whose non- } \\
\text { performing loan (NPL) ratio, measured as total bank NPL to } \\
\text { total loans, is in the top } 10 \% \text { (excluding state-owned banks) }\end{array}$ & $2.48 \%$ & $15.55 \%$ \\
\hline$B N K L E V 10 \%$ & $=$ & $\begin{array}{l}1 \text { if a firm borrows from at least one bank whose leverage, } \\
\text { measured as total assets to total debt, is in the top } 10 \% \\
\text { (excluding state-owned banks) }\end{array}$ & $19.62 \%$ & $39.71 \%$ \\
\hline BNKROE $10 \%$ & $=$ & $\begin{array}{l}1 \text { if a firm borrows from at least one bank whose ROE, } \\
\text { measured as the ratio of profits to equity, is in the bottom } \\
10 \% \text { (excluding state-owned banks) }\end{array}$ & $2.10 \%$ & $14.35 \%$ \\
\hline \multicolumn{5}{|c|}{ Firm Opacity/Relationship Variables } \\
\hline$S I Z E$ & $=$ & $\begin{array}{l}\text { The sum of the firm's total loans from all banks (not } \\
\text { included in regressions) }\end{array}$ & $\begin{array}{c}662,148 \\
\text { pesos }\end{array}$ & $\begin{array}{l}6,376,926 \\
\text { pesos }\end{array}$ \\
\hline$L N S I Z E$ & $=$ & $\begin{array}{l}\text { Natural log of the sum of the firm's total loans from all } \\
\text { banks }\end{array}$ & $\begin{array}{l}10.68 \\
\text { pesos }\end{array}$ & $\begin{array}{c}1.90 \\
\text { pesos }\end{array}$ \\
\hline$D E L I N Q$ & $=$ & Proportion of loans greater than 60 days past-due & 15.92 & 35.46 \\
\hline MULTIPLE & $=$ & 1 if a firm has loans from more than one bank & $43.95 \%$ & $49.63 \%$ \\
\hline \multicolumn{5}{|c|}{ Firm Industry Variables } \\
\hline Agriculture & $=$ & 1 if a firm's primary activity is Agriculture & $15.78 \%$ & $36.45 \%$ \\
\hline Fishing & $=$ & 1 if a firm's primary activity is Fishing & $0.20 \%$ & $4.49 \%$ \\
\hline Mining & $=$ & 1 if a firm's primary activity is Mining & $3.01 \%$ & $17.07 \%$ \\
\hline Utilities & $=$ & 1 if a firm's primary activity is Utilities & $0.92 \%$ & $9.52 \%$ \\
\hline Construction & $=$ & 1 if a firm's primary activity is Construction & $9.15 \%$ & $28.83 \%$ \\
\hline Commercial & $=$ & 1 if a firm's primary activity is Commercial & $35.25 \%$ & $47.78 \%$ \\
\hline
\end{tabular}




\section{Table 2: Definitions and Summary Statistics for Variables Used to Test the Secondary Hypotheses}

Summary statistics are for the sample of firms used to test the Single-Bank Firm Opacity and Multiple-Bank Distress Hypotheses. The total number of observations is 61,295, which excludes all firms whose primary bank is state-owned and firms with total bank loans less than 2,000 pesos.

\begin{tabular}{|c|c|c|c|c|}
\hline Variable Name & & Definition & Mean & Std Dev \\
\hline \multicolumn{5}{|c|}{ Multiple Bank Variable (Dependent Variable) } \\
\hline MULTIPLE & $=$ & 1 if a firm has loans from more than one bank & $43.95 \%$ & $49.63 \%$ \\
\hline \multicolumn{5}{|c|}{$\begin{array}{c}\text { Firm Opacity Variables } \\
\end{array}$} \\
\hline$S I Z E$ & $=$ & The sum of the firm's total loans from all banks. & $\begin{array}{c}662,148 \\
\text { pesos }\end{array}$ & $\begin{array}{l}6,376,926 \\
\text { pesos }\end{array}$ \\
\hline LNSIZE & $=$ & $\begin{array}{l}\text { Logged value of the sum of the firm's total loans from all } \\
\text { banks }\end{array}$ & $\begin{array}{l}10.68 \\
\text { pesos }\end{array}$ & $\begin{array}{c}1.90 \\
\text { pesos }\end{array}$ \\
\hline DELINQ & $=$ & Proportion of loans greater than 60 days past-due & 15.92 & 35.46 \\
\hline \multicolumn{5}{|c|}{ Primary Bank Distress Variables } \\
\hline$B N K N P L 10 \% P R I$ & $=$ & $\begin{array}{l}1 \text { if a firm's primary bank's non-performing loan (NPL) } \\
\text { ratio, measured as total bank NPL to total loans, is in the } \\
\text { top } 10 \% \text { (excluding state-owned banks) }\end{array}$ & $1.38 \%$ & $11.67 \%$ \\
\hline$B N K L E V 10 \% P R I$ & $=$ & $\begin{array}{l}1 \text { if a firm's primary bank's leverage, measured as total } \\
\text { assets to total debt, is in the top } 10 \% \text { (excluding state- } \\
\text { owned banks) }\end{array}$ & $13.36 \%$ & $34.02 \%$ \\
\hline BNKROE10\%PRI & $=$ & $\begin{array}{l}1 \text { if a firm's primary bank's ROE, measured as the ratio of } \\
\text { profits to liquid assets, is in the Smallest } 10 \% \text { (excluding } \\
\text { state-owned banks) }\end{array}$ & $0.75 \%$ & $8.60 \%$ \\
\hline \multicolumn{5}{|c|}{ Other Primary Bank Variables } \\
\hline BNKASSET10\%PRI & $=$ & $\begin{array}{l}1 \text { if a firm's primary bank is in the largest } 10 \% \text { of banks } \\
\text { ranked by asset size (excluding state-owned banks) }\end{array}$ & $52.55 \%$ & $49.94 \%$ \\
\hline FOREIGNPRI & $=$ & 1 if a firm's primary bank is foreign & $40.66 \%$ & $49.12 \%$ \\
\hline \multicolumn{5}{|c|}{ Firm Industry Variables } \\
\hline Agriculture & $=$ & 1 if a firm's primary activity is Agriculture & $15.78 \%$ & $36.45 \%$ \\
\hline Fishing & $=$ & 1 if a firm's primary activity is Fishing & $0.20 \%$ & $4.49 \%$ \\
\hline Mining & $=$ & 1 if a firm's primary activity is Mining & $3.01 \%$ & $17.07 \%$ \\
\hline Utilities & $=$ & 1 if a firm's primary activity is Utilities & $0.92 \%$ & $9.52 \%$ \\
\hline Construction & $=$ & 1 if a firm's primary activity is Construction & $9.15 \%$ & $28.83 \%$ \\
\hline Commercial & $=$ & 1 if a firm's primary activity is Commercial & $35.25 \%$ & $47.78 \%$ \\
\hline
\end{tabular}


Table 3: Tests of Large-Bank Barriers Hypothesis

\begin{tabular}{|c|c|c|c|c|c|c|c|c|c|c|c|c|c|c|c|c|c|c|}
\hline \multicolumn{19}{|c|}{ Logit Regression: Dependent Variable $=$ BNKASSET10 $\%$} \\
\hline & \multicolumn{6}{|c|}{$\begin{array}{c}\text { Smallest } 25 \% \\
(\leq 10,000 \text { Pesos })\end{array}$} & \multicolumn{6}{|c|}{$\begin{array}{c}\text { Smallest 50\% } \\
(\leq 33,600 \text { Pesos })\end{array}$} & \multicolumn{6}{|c|}{ All Firms } \\
\hline & \multicolumn{2}{|c|}{ (1) } & \multicolumn{2}{|c|}{ (2) } & \multicolumn{2}{|c|}{ (3) } & \multicolumn{2}{|c|}{ (4) } & \multicolumn{2}{|c|}{ (5) } & \multicolumn{2}{|c|}{ (6) } & \multicolumn{2}{|c|}{ (7) } & \multicolumn{2}{|c|}{ (8) } & \multicolumn{2}{|c|}{ (9) } \\
\hline & Coef & t-Stat & Coef & t-Stat & Coef & t-Stat & Coef & t-Stat & Coef & t-Stat & Coef & t-Stat & Coef & t-Stat & Coef & t-Stat & Coef & t-Stat \\
\hline Intercept & $-4.45^{* * * *}$ & 13.97 & $-5.43^{* * * *}$ & 15.38 & $-5.29^{* * * *}$ & 14.74 & $-1.62^{* * * *}$ & 11.22 & $-1.85^{* * * *}$ & 11.60 & $-0.56^{* * * *}$ & 3.37 & $-2.20^{* * * *}$ & 40.18 & $-2.51^{* * * *}$ & 41.47 & $-0.90^{* * * *}$ & 13.72 \\
\hline LNSIZE & $0.55^{* * * *}$ & 14.84 & $0.66^{* * * * *}$ & 16.10 & $0.64^{* * * *}$ & 15.24 & $0.21^{* * * *}$ & 13.55 & $0.24^{* * * *}$ & 13.56 & $0.08^{* * * *}$ & 4.31 & $0.26^{* * * *}$ & 49.31 & $0.29^{* * * * *}$ & 49.93 & $0.10^{* * * *}$ & 15.15 \\
\hline DELINQ & & & $5.26^{* * * *}$ & 6.21 & $5.58^{* * * * *}$ & 6.51 & & & $1.31^{* * * * *}$ & 3.48 & $0.91^{* * *}$ & 2.37 & & & $2.09^{* * * * *}$ & 13.41 & $2.04^{* * * * *}$ & 12.70 \\
\hline LNSIZE*DELINQ & & & $-0.60^{\text {**** }}$ & 6.02 & $-0.63^{\text {**** }}$ & 6.29 & & & $-0.13^{\text {**** }}$ & 3.17 & $-0.08^{*}$ & 1.86 & & & $-0.21^{* * * * *}$ & 13.97 & $-0.19^{* * * *}$ & 12.49 \\
\hline MULTIPLE & & & & & $1.35^{* * * *}$ & 21.69 & & & & & $1.44^{* * * *}$ & 40.07 & & & & & $1.58^{* * * *}$ & 66.69 \\
\hline Agriculture & $-0.79^{* * * *}$ & 14.29 & $-0.77^{* * * *}$ & 14.02 & $-0.96^{* * * *}$ & 16.74 & $-0.63^{* * * *}$ & 17.12 & $-0.62^{* * * *}$ & 16.81 & $-0.84^{* * * *}$ & 21.62 & $-0.22^{* * * *}$ & 9.10 & $-0.23^{* * * *}$ & 9.41 & $-0.47^{* * * 4}$ & 17.99 \\
\hline Fishing & 0.31 & 0.65 & 0.28 & 0.59 & 0.02 & 0.04 & 0.39 & 1.18 & 0.38 & 1.15 & 0.24 & 0.71 & $0.51^{* *}$ & 2.29 & $0.51^{* *}$ & 2.26 & 0.33 & 1.43 \\
\hline Mining & $2.26^{* * * * *}$ & 10.31 & $2.24^{* * * * *}$ & 10.22 & $1.89^{* * * * *}$ & 8.52 & $1.93^{* * * *}$ & 13.73 & $1.92^{\text {****** }}$ & 13.66 & $1.50^{* * * * *}$ & 10.51 & $1.84^{* * * * * *}$ & 19.70 & $1.83^{* * * *}$ & 19.58 & $1.43^{* * * *}$ & 15.08 \\
\hline Utilities & $0.53^{* *}$ & 2.22 & $0.54^{* * 4}$ & 2.23 & 0.25 & 0.99 & $0.55^{* * * *}$ & 3.19 & $0.55^{* * * *}$ & 3.22 & 0.22 & 1.21 & $0.56^{\text {***** }}$ & 4.95 & $0.54^{* * * a}$ & 4.76 & $0.29^{\text {** }}$ & 2.47 \\
\hline Construction & $0.40^{* * * *}$ & 5.16 & $0.40^{* * * * *}$ & 5.10 & $0.24^{* * * *}$ & 3.02 & $0.43^{* 2 * a}$ & 8.28 & $0.43^{* * * *}$ & 8.24 & $0.20^{* * * * *}$ & 3.65 & $0.48^{* * * *}$ & 13.98 & $0.49^{* * * *}$ & 14.07 & $0.26^{* * * *}$ & 7.26 \\
\hline Commercial & $-0.20^{* * * *}$ & 5.44 & $-0.20^{* * * *}$ & 5.39 & $-0.32^{* * * *}$ & 8.45 & $-0.09^{* * * *}$ & 3.68 & $-0.09^{* * * *}$ & 3.59 & $-0.32^{* * * *}$ & 11.92 & $0.10^{* * * *}$ & 5.43 & $0.10^{* * * *}$ & 5.34 & $-0.23^{* * * *}$ & 11.39 \\
\hline $\begin{array}{l}\text { Economic Significance: } \\
\text { SIZE x2 }(\% \Delta)\end{array}$ & $16.83 \%$ & & $17.16 \%$ & & $16.43 \%$ & & $6.18 \%$ & & $6.41 \%$ & & $1.97 \%$ & & $6.11 \%$ & & $6.03 \%$ & & $1.68 \%$ & \\
\hline $\begin{array}{l}\text { Economic Significance: } \\
\text { MULTIPLE } 0 \text { to } 1(\% \Delta)\end{array}$ & & & & & $185.4 \%$ & & & & & & $150.3 \%$ & & & & & & $80.33 \%$ & \\
\hline & 15270 & & 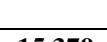 & & $4-9$ & & $80-7$ & & $80-7$ & & $80-7$ & & 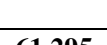 & & $90=$ & & (1) & \\
\hline
\end{tabular}

$*, * *, * * *$ represent significance at the $10 \%, 5 \%$, and $1 \%$ levels, respectively. 
Table 4: Tests of Foreign-Owned Bank Barriers Hypothesis

\begin{tabular}{|c|c|c|c|c|c|c|c|c|c|c|c|c|c|c|c|c|c|c|}
\hline \multicolumn{19}{|c|}{ Logit Regression: Dependent Variable = FOREIGN } \\
\hline & \multicolumn{6}{|c|}{$\begin{array}{c}\text { Smallest } 25 \% \\
(\leq 10,000 \text { Pesos })\end{array}$} & \multicolumn{6}{|c|}{$\begin{array}{c}\text { Smallest 50\% } \\
(\leq 33,600 \text { Pesos })\end{array}$} & \multicolumn{6}{|c|}{ All Firms } \\
\hline & \multicolumn{2}{|c|}{ (1) } & \multicolumn{2}{|c|}{$(2)$} & \multicolumn{2}{|c|}{ (3) } & \multicolumn{2}{|c|}{ (4) } & \multicolumn{2}{|c|}{$(5)$} & \multicolumn{2}{|c|}{ (6) } & \multicolumn{2}{|c|}{ (7) } & \multicolumn{2}{|c|}{ (8) } & \multicolumn{2}{|c|}{ (9) } \\
\hline & Coef & t-Stat & Coef & $\mathrm{t}-\mathrm{Stat}$ & Coef & t-Stat & Coef & t-Stat & Coef & t-Stat & Coef & $\mathrm{t}$-Stat & Coef & $\mathrm{t}$-Stat & Coef & t-Stat & Coef & $\mathrm{t}$-Stat \\
\hline Intercept & $-2.37^{* *}$ & 7.29 & $-2.95^{* * * *}$ & 8.13 & $-2.69^{* * * *}$ & 7.28 & $-2.17^{* * * *}$ & 14.86 & $-2.54^{* * * *}$ & 15.53 & $-1.21^{* * * *}$ & 7.08 & $-3.12^{* * * *}$ & 58.47 & $-3.40^{* * * *}$ & 57.96 & $-2.04^{* * * *}$ & 32.65 \\
\hline LNSIZE & $0.24^{* * * * *}$ & 6.32 & $0.30^{* * * * *}$ & 7.10 & $0.26^{* * * *}$ & 6.03 & $0.21^{* * * * *}$ & 13.35 & $0.25^{* * * *}$ & 13.98 & $0.08^{* * * * *}$ & 4.51 & $0.30^{* * * * *}$ & 59.40 & $0.33^{* * * * *}$ & 58.94 & $0.16^{* * * *}$ & 25.87 \\
\hline DELINQ & & & $2.36^{* * * *}$ & 2.79 & $2.59^{* * * *}$ & 3.03 & & & $1.93^{* * * * *}$ & 5.14 & $1.53^{* * * * *}$ & 4.01 & & & $1.95^{* * * *}$ & 12.75 & $1.98^{* * * *}$ & 12.73 \\
\hline LNSIZE*DELINQ & & & $-0.24^{* * *}$ & 2.39 & $-0.26^{* * * *}$ & 2.58 & & & $-0.19^{* * * *}$ & 4.67 & $-0.14^{* * * *}$ & 3.31 & & & $-0.19^{* * * *}$ & 12.82 & $-0.18^{* * * *}$ & 12.04 \\
\hline MULTIPLE & & & & & $1.25^{* * * * *}$ & 22.86 & & & & & $1.33^{* * * * *}$ & 41.01 & & & & & $1.41^{* * * * *}$ & 65.05 \\
\hline Agriculture & $-1.03^{* * * *}$ & 16.12 & $-1.01^{* * * *}$ & 15.68 & $-1.21^{* * * *}$ & 18.19 & $-0.94^{* * * * *}$ & 22.68 & $-0.93^{* * * *}$ & 22.29 & $-1.17^{* * a *}$ & 26.76 & $-0.70^{* * * * * *}$ & 28.65 & $-0.71^{\text {*iak }}$ & 28.70 & $-0.96^{* * * a *}$ & 36.94 \\
\hline Fishing & 0.65 & 1.40 & 0.61 & 1.30 & 0.36 & 0.73 & $0.64^{* * *}$ & 2.05 & $0.63^{* *}$ & 2.01 & 0.52 & 1.61 & $1.05^{* * * *}$ & 4.63 & $1.05^{* * * *}$ & 4.60 & $0.94^{* * * *}$ & 4.01 \\
\hline Mining & $2.01^{* * * * *}$ & 12.49 & $1.98^{* * * *}$ & 12.30 & $1.64^{* * * *}$ & 9.97 & $1.74^{* * * *}$ & 16.20 & $1.73^{* * * * *}$ & 16.05 & $1.33^{* * * *}$ & 12.09 & $1.57^{* * * *}$ & 22.29 & $1.56^{* * * *}$ & 22.13 & $1.21^{* * * *}$ & 16.85 \\
\hline Utilities & $0.79^{* * * *}$ & 3.46 & $0.80^{* * * *}$ & 3.52 & $0.53^{* *}$ & 2.26 & $0.83^{* * * *}$ & 5.10 & $0.84^{* * * *}$ & 5.16 & $0.54^{* * * *}$ & 3.18 & $0.74^{* * * * *}$ & 6.96 & $0.73^{\text {***** }}$ & 6.85 & $0.52^{* * * *}$ & 4.76 \\
\hline Construction & $0.37^{* * * * *}$ & 5.04 & $0.37^{* * * * *}$ & 4.95 & $0.21^{* * * *}$ & 2.80 & $0.52^{* * * *}$ & 10.48 & $0.51^{* * * * *}$ & 10.43 & $0.30^{* * * * *}$ & 5.85 & $0.61^{* * * * *}$ & 18.89 & $0.61^{* * * *}$ & 18.93 & $0.42^{* * * *}$ & 12.69 \\
\hline Commercial & $-0.25^{* * * *}$ & 6.60 & $-0.24^{* * * * *}$ & 6.49 & $-0.37^{* * * *}$ & 9.53 & $-0.08^{* * * *}$ & 3.25 & $-0.08^{* * * *}$ & 3.10 & $-0.31^{* * * *}$ & 11.32 & $0.12^{2 * * * * * *}$ & 6.85 & $0.12^{* * * *}$ & 6.85 & $-0.18^{* * * *}$ & 8.98 \\
\hline $\begin{array}{l}\text { Economic Significance: } \\
\text { SIZE x }(\% \Delta)\end{array}$ & $10.24 \%$ & & $11.13 \%$ & & $9.26 \%$ & & $8.38 \%$ & & $8.69 \%$ & & $2.23 \%$ & & $9.70 \%$ & & $9.69 \%$ & & $4.27 \%$ & \\
\hline $\begin{array}{l}\text { Economic Significance: } \\
\text { MULTIPLE } 0 \text { to } 1(\% \Delta)\end{array}$ & & & & & $167.9 \%$ & & & & & & $137.4 \%$ & & & & & & $73.65 \%$ & \\
\hline Observations: & 15,379 & & 15.379 & & 15,379 & & 30,657 & & 30,657 & & 30,657 & & 61.295 & & 61.295 & & 61,295 & \\
\hline
\end{tabular}

\footnotetext{
$*, * *, * * *$ represent significance at the $10 \%, 5 \%$, and $1 \%$ levels, respectively.
} 
Table 5: Tests of Foreign-Owned Bank Barriers Hypothesis for Banks Headquartered in other South American Countries

\begin{tabular}{|c|c|c|c|c|c|c|c|c|c|c|c|c|c|c|c|c|c|c|}
\hline \multicolumn{19}{|c|}{ Logit Regression: Dependent Variable $=$ FOREIGN-SA } \\
\hline & \multicolumn{6}{|c|}{$\begin{array}{c}\text { Smallest } 25 \% \\
(\leq 10,000 \text { Pesos })\end{array}$} & \multicolumn{6}{|c|}{$\begin{array}{c}\text { Smallest 50\% } \\
(\leq 33,600 \text { Pesos })\end{array}$} & \multicolumn{6}{|c|}{ All Firms } \\
\hline & \multicolumn{2}{|c|}{ (1) } & \multicolumn{2}{|c|}{ (2) } & \multicolumn{2}{|c|}{ (3) } & \multicolumn{2}{|c|}{ (4) } & \multicolumn{2}{|c|}{ (5) } & \multicolumn{2}{|c|}{ (6) } & \multicolumn{2}{|c|}{ (7) } & \multicolumn{2}{|c|}{ (8) } & \multicolumn{2}{|c|}{ (9) } \\
\hline & Coef & t-Stat & Coef & t-Stat & Coef & t-Stat & Coef & t-Stat & Coef & t-Stat & Coef & t-Stat & Coef & t-Stat & Coef & t-Stat & Coef & t-Stat \\
\hline Intercept & $-4.26^{* * * *}$ & 5.58 & $-4.23^{* * * *}$ & 4.84 & $-3.69^{* * * *}$ & 4.19 & $-5.29^{* * * *}$ & 16.07 & $-4.76^{* * * *}$ & 12.38 & $-3.39^{* * * * *}$ & 8.63 & $-6.46^{* * * *}$ & 77.79 & $-6.97^{* * * *}$ & 74.27 & $-6.52^{* * *}$ & 67.20 \\
\hline LNSIZE & 0.14 & 1.59 & 0.13 & 1.26 & 0.05 & 0.47 & $0.25^{* * * *}$ & 7.09 & $0.18^{* * * *}$ & 4.26 & 0.00 & 0.06 & $0.36^{* * * *}$ & 50.50 & $0.39^{* * * *}$ & 49.77 & $0.31^{* * * *}$ & 36.57 \\
\hline DELINQ & & & -0.87 & 0.47 & -0.70 & 0.38 & & & $-1.66^{* * *}$ & 2.19 & $-2.13^{* * * *}$ & 2.80 & & & $2.15^{* * * *}$ & 9.35 & $2.61^{* * * * *}$ & 11.12 \\
\hline LNSIZE*DELINQ & & & 0.15 & 0.70 & 0.14 & 0.64 & & & $0.25^{* \text { *a* }}$ & 3.08 & $0.31^{\text {*a* }}$ & 3.84 & & & $-0.14^{\text {*Na* }}$ & 6.55 & $-0.17^{* * 3 * \pi}$ & 7.94 \\
\hline MULTIPLE & & & & & $1.23^{* * * *}$ & 12.60 & & & & & $1.13^{* * * * *}$ & 19.11 & & & & & $0.90^{* * * *}$ & 24.88 \\
\hline Agriculture & -0.18 & 1.34 & -0.15 & 1.07 & $-0.35^{* *}$ & 2.48 & $-0.18^{* *}$ & 2.05 & -0.11 & 1.18 & $-0.28^{* * * *}$ & 3.08 & -0.02 & 0.55 & 0.03 & 0.72 & $-0.08^{* *}$ & 2.07 \\
\hline Fishing & $1.48^{* * *}$ & 2.41 & $1.42^{* *}$ & 2.30 & $1.15^{*}$ & 1.74 & $1.00^{\text {*** }}$ & 2.19 & $1.03^{* * *}$ & 2.21 & $0.87^{*}$ & 1.79 & $0.98^{\text {******** }}$ & 4.39 & $0.98^{* * * * *}$ & 4.38 & $0.87^{\text {******** }}$ & 3.82 \\
\hline Mining & $-0.95^{*}$ & 2.09 & $-1.00^{* *}$ & 2.19 & $-1.53^{\text {***** }}$ & 3.31 & $-0.55^{* *}$ & 2.22 & $-0.56^{* * *}$ & 2.29 & $-1.03^{* * * * *}$ & 4.12 & $0.23^{\text {******* }}$ & 3.23 & $0.23^{* * * *}$ & 3.16 & 0.07 & 0.92 \\
\hline Utilities & -0.75 & 1.03 & -0.73 & 1.00 & -1.21 & 1.63 & -0.39 & 0.97 & -0.31 & 0.76 & $-0.72^{*}$ & 1.76 & 0.11 & 0.87 & 0.13 & 1.08 & 0.05 & 0.38 \\
\hline Construction & $2.24^{* * * * *}$ & 24.02 & $2.24^{* * * * *}$ & 23.94 & $2.12^{* * * *}$ & 22.63 & $2.29^{* * * *}$ & 38.18 & $2.30^{\text {******at }}$ & 37.95 & $2.15^{* * * *}$ & 35.26 & $1.90^{* * * * *}$ & 56.28 & $1.90^{* * * *}$ & 56.09 & $1.82^{* * * *}$ & 53.22 \\
\hline Commercial & $-1.17^{* * * *}$ & 9.21 & $-1.16^{* * * *}$ & 9.14 & $-1.40^{* * * *}$ & 10.79 & $-0.67^{* * * *}$ & 9.89 & $-0.64^{* * * *}$ & 9.44 & $-0.94^{* * * *}$ & 13.30 & $-0.09^{* * * *}$ & 2.82 & $-0.07^{* *}$ & 2.19 & $-0.27^{* * * *}$ & 8.47 \\
\hline $\begin{array}{l}\text { Economic Significance: } \\
\text { SIZE x }(\% \Delta)\end{array}$ & $9.66 \%$ & & $10.72 \%$ & & $4.94 \%$ & & $17.65 \%$ & & $15.57 \%$ & & $3.49 \%$ & & $24.62 \%$ & & $25.20 \%$ & & $18.95 \%$ & \\
\hline $\begin{array}{l}\text { Economic Significance: } \\
\text { MULTIPLE } 0 \text { to } 1(\% \Delta)\end{array}$ & & & & & $164.3 \%$ & & & & & & $113.9 \%$ & & & & & & $50.01 \%$ & \\
\hline Obsotion & & & & & & & & & & & & & $5120=$ & & & & $9120=$ & \\
\hline
\end{tabular}

$*, * *, * * *$ represent significance at the $10 \%, 5 \%$, and $1 \%$ levels, respectively. 
Table 6: Tests of Foreign-Owned Bank Barriers Hypothesis for Banks Headquartered in Non-South American Countries

\begin{tabular}{|c|c|c|c|c|c|c|c|c|c|c|c|c|c|c|c|c|c|c|}
\hline \multicolumn{19}{|c|}{ Logit Regression: Dependent Variable $=$ FOREIGN-NSA } \\
\hline & \multicolumn{6}{|c|}{$\begin{array}{c}\text { Smallest } 25 \% \\
(\leq 10,000 \text { Pesos })\end{array}$} & \multicolumn{6}{|c|}{$\begin{array}{c}\text { Smallest 50\% } \\
(\leq 33,600 \text { Pesos })\end{array}$} & \multicolumn{6}{|c|}{ All Firms } \\
\hline & \multicolumn{2}{|c|}{ (1) } & \multicolumn{2}{|c|}{$(2)$} & \multicolumn{2}{|c|}{ (3) } & \multicolumn{2}{|c|}{ (4) } & \multicolumn{2}{|c|}{$(5)$} & \multicolumn{2}{|c|}{ (6) } & \multicolumn{2}{|c|}{ (7) } & \multicolumn{2}{|c|}{ (8) } & \multicolumn{2}{|c|}{ (9) } \\
\hline & Coef & t-Stat & Coef & t-Stat & Coef & t-Stat & Coef & t-Stat & Coef & t-Stat & Coef & t-Stat & Coef & t-Stat & Coef & t-Stat & Coef & t-Stat \\
\hline Intercept & $-2.45^{* * * *}$ & 7.30 & $-3.08^{* * * *}$ & 8.23 & $-2.87^{* * * *}$ & 7.57 & $-1.99^{* * * *}$ & 13.30 & $-2.53^{* * * *}$ & 15.14 & $-1.43^{* * * *}$ & 8.24 & $-1.63^{\text {**** }}$ & 33.40 & $-1.75^{* * * *}$ & 33.14 & $-0.68^{* * * *}$ & 11.92 \\
\hline LNSIZE & $0.23^{* * * *}$ & 5.78 & $0.29^{* * * * *}$ & 6.76 & $0.26^{* * * *}$ & 5.90 & $0.17^{* * * *}$ & 10.45 & $0.23^{\text {***** }}$ & 12.59 & $0.09^{* * * *}$ & 4.84 & $0.13^{* * * *}$ & 28.53 & $0.15^{* * * *}$ & 29.47 & 0.01 & 1.48 \\
\hline DELINQ & & & $2.81^{2 * * *}$ & 3.25 & $3.00^{* * * * *}$ & 3.43 & & & $2.84^{* * * * *}$ & 7.40 & $2.57^{* * * * *}$ & 6.60 & & & $1.17^{* * * * 4}$ & 7.80 & $1.33^{* * * *}$ & 8.66 \\
\hline LNSIZE*DELINQ & & & $-0.30^{* * * * *}$ & 2.93 & $-0.32^{* * * * *}$ & 3.09 & & & $-0.31^{* * * * *}$ & 7.36 & $-0.27^{* * * * *}$ & 6.39 & & & $-0.13^{* * * * *}$ & 9.20 & $-0.14^{* * * * *}$ & 9.53 \\
\hline MULTIPLE & & & & & $0.99^{2 * * a *}$ & 18.52 & & & & & $1.07^{* * a *}$ & 33.80 & & & & & $1.14^{* * * \pi *}$ & 54.28 \\
\hline Agriculture & $-1.09^{* * * *}$ & 15.85 & $-1.07^{* * * * *}$ & 15.52 & $-1.23^{* * * *}$ & 17.33 & $-0.98^{* * * *}$ & 22.12 & $-0.98^{* * * *}$ & 22.13 & $-1.16^{* * * *}$ & 25.43 & $-0.67^{* * *}$ & 27.24 & $-0.69^{* * * *}$ & 27.82 & $-0.87^{* * * *}$ & 33.92 \\
\hline Fishing & 0.08 & 0.18 & 0.05 & 0.09 & -0.18 & 0.38 & 0.33 & 1.06 & 0.31 & 1.00 & 0.20 & 0.63 & $0.35^{*}$ & 1.91 & $0.35^{*}$ & 1.91 & 0.22 & 1.20 \\
\hline Mining & $2.08^{* * * *}$ & 13.40 & $2.05^{* * * *}$ & 13.22 & $1.77^{* * * *}$ & 11.22 & $1.76^{* * * *}$ & 17.34 & $1.75^{* * * *}$ & 17.23 & $1.43^{* * * * *}$ & 13.75 & $0.98^{* * * *}$ & 18.86 & $0.97^{* * * *}$ & 18.72 & $0.72^{* * * *}$ & 13.65 \\
\hline Utilities & $0.90^{* * * * *}$ & 3.97 & $0.91^{* * * * *}$ & 4.02 & $0.69^{* * * *}$ & 2.98 & $0.90^{* * * * *}$ & 5.63 & $0.89^{* * * *}$ & 5.57 & $0.64^{* * * * *}$ & 3.90 & $0.38^{* * * * *}$ & 4.26 & $0.35^{* * * *}$ & 3.90 & $0.21^{\text {*** }}$ & 2.32 \\
\hline Construction & $-0.79^{* * * *}$ & 8.84 & $-0.80^{* * * * *}$ & 8.93 & $-0.96^{* * * *}$ & 10.51 & $-0.70^{\text {**** }}$ & 12.60 & $-0.70^{* * * *}$ & 12.58 & $-0.94^{* * * *}$ & 16.32 & $-0.70^{* * * *}$ & 22.38 & $-0.69^{* * * * *}$ & 22.27 & $-0.88^{* * * * *}$ & 27.72 \\
\hline Commercial & $-0.11^{* * * *}$ & 2.90 & $-0.11^{* * * * *}$ & 2.82 & $-0.20^{* * * *}$ & 5.09 & 0.03 & 1.02 & 0.03 & 0.98 & $-0.15^{* * * *}$ & 5.48 & $0.14^{* * * *}$ & 7.98 & $0.14^{* * * *}$ & 7.77 & $-0.09^{* * * *}$ & 4.83 \\
\hline $\begin{array}{l}\text { Economic Significance: } \\
\text { SIZE x }(\% \Delta)\end{array}$ & $10.66 \%$ & & $11.16 \%$ & & $9.59 \%$ & & $7.50 \%$ & & $7.83 \%$ & & $1.93 \%$ & & $5.23 \%$ & & $5.20 \%$ & & $-0.49 \%$ & \\
\hline $\begin{array}{l}\text { Economic Significance: } \\
\text { MULTIPLE } 0 \text { to } 1(\% \Delta)\end{array}$ & & & & & $123.4 \%$ & & & & & & $106.9 \%$ & & & & & & $61.78 \%$ & \\
\hline Observations: & 15,379 & & 15,379 & & 15,379 & & 30,657 & & 30,657 & & 30,657 & & 61,295 & & 61,295 & & 61,295 & \\
\hline
\end{tabular}

$*, * *, * * *$ represent significance at the $10 \%, 5 \%$, and $1 \%$ levels, respectively. 
Table 7: Tests of Distressed-Bank Barriers (NPL) Hypotheses

\begin{tabular}{|c|c|c|c|c|c|c|c|c|c|c|c|c|c|c|c|c|c|c|}
\hline \multicolumn{19}{|c|}{ Logit Regression: Dependent Variable $=$ BNKNPL10 $\%$} \\
\hline & \multicolumn{6}{|c|}{$\begin{array}{c}\text { Smallest } 25 \% \\
(\leq 10,000 \text { Pesos })\end{array}$} & \multicolumn{6}{|c|}{$\begin{array}{c}\text { Smallest } 50 \% \\
(\leq 33,600 \text { Pesos })\end{array}$} & \multicolumn{6}{|c|}{ All Firms } \\
\hline & \multicolumn{2}{|c|}{$(1)$} & \multicolumn{2}{|c|}{$(2)$} & \multicolumn{2}{|c|}{ (3) } & \multicolumn{2}{|c|}{ (4) } & \multicolumn{2}{|c|}{$(5)$} & \multicolumn{2}{|c|}{ (6) } & \multicolumn{2}{|c|}{ (7) } & \multicolumn{2}{|c|}{$(8)$} & \multicolumn{2}{|c|}{ (9) } \\
\hline & Coef & $\mathrm{t}$-Stat & Coef & t-Stat & Coef & $\mathrm{t}$-Stat & Coef & t-Stat & Coef & $\mathrm{t}$-Stat & Coef & $\mathrm{t}$-Stat & Coef & $\mathrm{t}$-Stat & Coef & $\mathrm{t}$-Stat & Coef & $\mathrm{t}$-Stat \\
\hline Intercept & $-3.45^{* * * *}$ & 2.63 & $-4.46^{* * * *}$ & 2.91 & $-4.10^{* * * *}$ & 2.67 & $-5.05^{* * * *}$ & 8.63 & $-5.62^{* * * *}$ & 8.29 & $-4.33^{* * * *}$ & 6.31 & $-6.57^{* * *}$ & 46.25 & $-6.52^{* * * *}$ & 40.70 & $-6.03^{* * * *}$ & 35.65 \\
\hline LNSIZE & -0.08 & 0.53 & 0.02 & 0.14 & -0.03 & 0.19 & 0.11 & 1.77 & $0.17^{* * *}$ & 2.28 & 0.00 & 0.02 & $0.26^{* * * *}$ & 21.60 & $0.25^{* * * *}$ & 18.17 & $0.17^{* * * *}$ & 10.96 \\
\hline DELINQ & & & 3.20 & 1.06 & 3.39 & 1.12 & & & $2.43^{*}$ & 1.79 & 2.05 & 1.51 & & & $-1.42^{* * * * *}$ & 3.49 & $-1.16^{* * * *}$ & 2.77 \\
\hline LNSIZE*DELINQ & & & -0.32 & 0.90 & -0.34 & 0.94 & & & -0.23 & 1.56 & -0.18 & 1.22 & & & $0.18^{* * * * a}$ & 5.23 & $0.17^{* * 2 * *}$ & 4.63 \\
\hline MULTIPLE & & & & & $1.08^{* * * * *}$ & 6.61 & & & & & $1.03^{* * * * *}$ & 9.91 & & & & & $0.83^{* * * *}$ & 12.61 \\
\hline Agriculture & $-0.71^{* * * * *}$ & 2.44 & $-0.66^{* *}$ & 2.27 & $-0.82^{* * * * *}$ & 2.80 & $-1.13^{* * * *}$ & 4.98 & $-1.10^{* * * * *}$ & 4.85 & $-1.23^{* * * *}$ & 5.43 & $-0.52^{* * * *}$ & 6.30 & $-0.48^{* * * *}$ & 5.77 & $-0.57^{* * * *}$ & 6.86 \\
\hline Fishing & -11.08 & 0.02 & -11.11 & 0.02 & -11.21 & 0.03 & -11.15 & 0.04 & -11.15 & 0.04 & -11.15 & 0.04 & -1.40 & 1.39 & -1.41 & 1.40 & -1.52 & 1.51 \\
\hline Mining & -1.51 & 1.50 & -1.57 & 1.56 & $-2.02^{* *}$ & 2.00 & $-1.20^{* *}$ & 2.07 & $-1.23^{* *}$ & 2.11 & $-1.62^{* * * *}$ & 2.78 & 0.11 & 0.84 & 0.14 & 1.10 & 0.00 & 0.00 \\
\hline Utilities & -0.24 & 0.24 & $\begin{array}{l}-0.22 \\
\end{array}$ & 0.22 & -0.58 & 0.57 & 0.58 & 1.27 & 0.60 & 1.32 & 0.30 & 0.65 & $\begin{array}{l}-0.09 \\
\end{array}$ & 0.42 & 0.01 & 0.04 & -0.03 & 0.15 \\
\hline Construction & -0.56 & 1.44 & -0.57 & 1.47 & $-0.74^{*}$ & 1.89 & $\begin{array}{l}-0.04 \\
\end{array}$ & 0.23 & -0.05 & 0.26 & -0.23 & 1.23 & $0.25^{* * * *}$ & 3.22 & $0.23^{* * * *}$ & 3.02 & $0.15^{*}$ & 1.94 \\
\hline Commercial & -0.04 & 0.24 & -0.03 & 0.19 & -0.14 & 0.91 & $-0.18^{*}$ & 1.72 & $-0.17^{*}$ & 1.65 & $-0.35^{* * * *}$ & 3.31 & 0.01 & 0.25 & 0.03 & 0.50 & $-0.14^{* * *}$ & 2.43 \\
\hline & & & & & & & & & & & & & & & & & & \\
\hline $\begin{array}{l}\text { Economic Significance: } \\
\text { SIZE x }(\% \Delta)\end{array}$ & $-5.32 \%$ & & $-2.21 \%$ & & $-5.71 \%$ & & $7.79 \%$ & & $9.35 \%$ & & $-2.06 \%$ & & $19.16 \%$ & & $20.67 \%$ & & $14.22 \%$ & \\
\hline $\begin{array}{l}\text { Economic Significance: } \\
\text { MULTIPLE } 0 \text { to } 1(\% \Delta)\end{array}$ & & & & & $138.3 \%$ & & & & & & $102.3 \%$ & & & & & & $46.40 \%$ & \\
\hline & & & & & & & & & & & & & & & & & & \\
\hline Observations: & 15,379 & & 15,379 & & 15,379 & & 30,657 & & 30,657 & & 30,657 & & 61,295 & & 61,295 & & 61,295 & \\
\hline
\end{tabular}

$*, * *, * * *$ represent significance at the $10 \%, 5 \%$, and $1 \%$ levels, respectively. 
Table 8: Tests of Distressed-Bank Barriers (LEV) Hypothesis

\begin{tabular}{|c|c|c|c|c|c|c|c|c|c|c|c|c|c|c|c|c|c|c|}
\hline \multicolumn{19}{|c|}{ Logit Regression: Dependent Variable = BNKLEV10\% } \\
\hline & \multicolumn{6}{|c|}{$\begin{array}{c}\text { Smallest } 25 \% \\
(\leq 10,000 \text { Pesos })\end{array}$} & \multicolumn{6}{|c|}{$\begin{array}{c}\text { Smallest } 50 \% \\
(\leq 33,600 \text { Pesos })\end{array}$} & \multicolumn{6}{|c|}{ All Firms } \\
\hline & \multicolumn{2}{|c|}{$(1)$} & \multicolumn{2}{|c|}{$(2)$} & \multicolumn{2}{|c|}{ (3) } & \multicolumn{2}{|c|}{ (4) } & \multicolumn{2}{|c|}{$(5)$} & \multicolumn{2}{|c|}{ (6) } & \multicolumn{2}{|c|}{ (7) } & \multicolumn{2}{|c|}{ (8) } & \multicolumn{2}{|c|}{ (9) } \\
\hline & Coef & t-Stat & Coef & $\mathrm{t}$-Stat & Coef & t-Stat & Coef & t-Stat & Coef & t-Stat & Coef & t-Stat & Coef & t-Stat & Coef & t-Stat & Coef & t-Stat \\
\hline Intercept & $0.84^{* * *}$ & 2.09 & $1.28^{* * * * a}$ & 2.87 & $1.42^{* * * * a}$ & 3.18 & $-1.20^{* * * * *}$ & 6.43 & $-1.41^{* * * * *}$ & 6.82 & $-0.65^{* * * *}$ & 3.07 & $-2.37^{* * * *}$ & 40.27 & $-2.45^{* * * * *}$ & 38.79 & $-1.86^{* * * * *}$ & 27.54 \\
\hline LNSIZE & $-0.27^{* * * *}$ & 5.66 & $-0.32^{* * * *}$ & 6.14 & $-0.34^{* * * * *}$ & 6.53 & -0.03 & 1.58 & -0.01 & 0.36 & $-0.10^{* * * * *}$ & 4.43 & $0.08^{* * * * *}$ & 15.48 & $0.09^{* * * * *}$ & 16.15 & $0.02^{* * * *}$ & 2.34 \\
\hline DELINQ & & & $-2.60^{* *}$ & 2.46 & $-2.55^{* *}$ & 2.41 & & & $1.15^{* * *}$ & 2.40 & $0.93^{*}$ & 1.94 & & & $0.84^{* * *}$ & 4.45 & $0.97^{* * * *}$ & 5.07 \\
\hline LNSIZE*DELINQ & & & $0.32^{* *}$ & 2.55 & $0.31^{* *}$ & 2.51 & & & $-0.13^{* * *}$ & 2.42 & $-0.10^{*}$ & 1.88 & & & $-0.09^{* * * * *}$ & 5.22 & $-0.10^{* * * * *}$ & 5.58 \\
\hline MULTIPLE & & & & & $0.50^{* * * *}$ & 8.02 & & & & & $0.66^{* * * *}$ & 17.91 & & & & & $0.65^{* * * *}$ & 26.34 \\
\hline Agriculture & -0.51 & 1.19 & $-1.06^{* * * *}$ & 11.05 & $-1.12^{* * * *}$ & 11.68 & -0.43 & 1.51 & $-0.97^{* * * *}$ & 15.14 & $-1.07^{* * * *}$ & 16.56 & $-0.17^{* * * *}$ & 2.23 & $-0.55^{* * * *}$ & 16.71 & $-0.64^{* * * *}$ & 19.25 \\
\hline Fishing & $2.22^{* * *}$ & 2.13 & -11.34 & 0.08 & -11.45 & 0.08 & 1.40 & 1.38 & $-2.23^{* *}$ & 2.21 & $-2.32^{* *}$ & 2.29 & 0.46 & 1.04 & -0.36 & 1.43 & $-0.44^{*}$ & 1.76 \\
\hline Mining & -0.48 & 0.47 & $-1.31^{* * * *}$ & 5.34 & $-1.51^{* * * *}$ & 6.10 & 0.24 & 0.47 & $-0.82^{* * * *}$ & 5.72 & $-1.09^{* * * *}$ & 7.49 & $0.23^{* *}$ & 1.99 & $-0.11^{*}$ & 1.78 & $-0.25^{* * * *}$ & 4.19 \\
\hline Utilities & -12.56 & 0.02 & -0.23 & 0.76 & -0.37 & 1.21 & 0.06 & 0.06 & -0.06 & 0.31 & -0.25 & 1.21 & $-0.44^{* * *}$ & 2.01 & 0.06 & 0.61 & 0.00 & 0.03 \\
\hline Construction & 0.53 & 1.40 & $-1.47^{* * * *}$ & 9.01 & $-1.54^{* * * *}$ & 9.45 & 0.10 & 0.32 & $-1.03^{* * * *}$ & 11.52 & $-1.17^{* * * *}$ & 12.98 & 0.08 & 0.97 & $-0.42^{* * * *}$ & 10.71 & $-0.52^{* * * *}$ & 13.00 \\
\hline Commercial & $-1.19^{* * * *}$ & 3.28 & $0.23^{* * * *}$ & 5.09 & $0.19^{* * * *}$ & 4.20 & $-0.78^{* * * *}$ & 3.66 & $0.28^{* * * *}$ & 8.73 & $0.18^{* * * *}$ & 5.52 & $0.11^{*}$ & 1.89 & $0.43^{* * * *}$ & 20.53 & $0.31^{* * * *}$ & 14.22 \\
\hline $\begin{array}{l}\text { Economic Significance: } \\
\text { SIZE x }(\% \Delta)\end{array}$ & $-14.44 \%$ & & $-14.30 \%$ & & $-15.38 \%$ & & $-1.70 \%$ & & $-1.82 \%$ & & $-6.50 \%$ & & $41.15 \%$ & & $4.28 \%$ & & $0.23 \%$ & \\
\hline $\begin{array}{l}\text { Economic Significance: } \\
\text { MULTIPLE } 0 \text { to } 1(\% \Delta)\end{array}$ & & & & & $53.19 \%$ & & & & & & $61.22 \%$ & & & & & & $36.78 \%$ & \\
\hline & & & & & & & & & & & & & & & & & & \\
\hline Observations: & 15,379 & & 15,379 & & 15,379 & & 30,657 & & 30,657 & & 30,657 & & 61,295 & & 61,295 & & 61,295 & \\
\hline
\end{tabular}

$*, * *, * * *$ represent significance at the $10 \%, 5 \%$, and $1 \%$ levels, respectively. 
Table 9: Tests of Distressed-Bank Barriers (ROE) Hypothesis

\begin{tabular}{|c|c|c|c|c|c|c|c|c|c|c|c|c|c|c|c|c|c|c|}
\hline \multicolumn{19}{|c|}{ Logit Regression: Dependent Variable $=$ BNKROE10 $\%$} \\
\hline & \multicolumn{6}{|c|}{$\begin{array}{c}\text { Smallest } 25 \% \\
(\leq 10,000 \text { Pesos })\end{array}$} & \multicolumn{6}{|c|}{$\begin{array}{c}\text { Smallest } 50 \% \\
(\leq 33,600 \text { Pesos })\end{array}$} & \multicolumn{6}{|c|}{ All Firms } \\
\hline & \multicolumn{2}{|c|}{ (1) } & \multicolumn{2}{|c|}{$(2)$} & \multicolumn{2}{|c|}{ (3) } & \multicolumn{2}{|c|}{ (4) } & \multicolumn{2}{|c|}{$(5)$} & \multicolumn{2}{|c|}{ (6) } & \multicolumn{2}{|c|}{ (7) } & \multicolumn{2}{|c|}{$(8)$} & \multicolumn{2}{|c|}{ (9) } \\
\hline & Coef & t-Stat & Coef & t-Stat & Coef & t-Stat & Coef & t-Stat & Coef & t-Stat & Coef & t-Stat & Coef & t-Stat & Coef & t-Stat & Coef & $\mathrm{t}$-Stat \\
\hline Intercept & $-6.92^{* * * *}$ & 3.02 & $-4.87^{*}$ & 1.81 & -3.99 & 1.48 & $-6.79^{* * * * *}$ & 6.58 & $-7.46^{* * * * *}$ & 6.25 & $-5.84^{* * * * *}$ & 4.86 & $-11.6^{* * * a *}$ & 63.88 & $-11.8^{* * * a *}$ & 59.82 & $-11.70^{* * * *}$ & 57.72 \\
\hline LNSIZE & 0.21 & 0.80 & -0.05 & 0.15 & -0.19 & 0.59 & $0.18^{*}$ & 1.65 & $0.25^{*}$ & 1.95 & 0.04 & 0.28 & $0.64^{* * * * *}$ & 47.49 & $0.66^{* * * *}$ & 45.36 & $0.61^{* * * *}$ & 39.21 \\
\hline DELINQ & & & -8.10 & 1.54 & -8.12 & 1.52 & & & 2.88 & 1.19 & 2.48 & 1.03 & & & $1.66^{* * * *}$ & 2.71 & $2.20^{* * * *}$ & 3.48 \\
\hline LNSIZE*DELINQ & & & $1.03^{*}$ & 1.69 & $1.05^{*}$ & 1.69 & & & -0.28 & 1.09 & -0.23 & 0.88 & & & $-0.13^{* *}$ & 2.50 & $-0.16^{* * * *}$ & 3.18 \\
\hline MULTIPLE & & & & & $1.70^{* * * *}$ & 6.73 & & & & & $1.37^{* * * *}$ & 7.72 & & & & & $0.75^{* * * *}$ & 8.40 \\
\hline Agriculture & $-1.06^{\text {**ater }}$ & 11.12 & $\begin{array}{l}-0.44 \\
-1\end{array}$ & 1.02 & -0.68 & 1.58 & $-0.97^{* * * k+k}$ & 15.13 & -0.41 & 1.43 & $-0.56^{* * * *}$ & 1.96 & $-0.54^{* * * * *}$ & 16.42 & $-0.16^{* * 4}$ & 2.09 & $-0.22^{* * * * *}$ & 2.84 \\
\hline Fishing & -11.34 & 0.08 & $2.12^{* * *}$ & 2.02 & 1.69 & 1.56 & $-2.22^{* *}$ & 2.20 & 1.38 & 1.36 & 1.24 & 1.21 & -0.36 & 1.43 & 0.47 & 1.07 & 0.38 & 0.86 \\
\hline Mining & $-1.30^{* * * *}$ & 5.31 & -0.57 & 0.56 & -1.29 & 1.27 & $-0.82^{* * * *}$ & 5.69 & 0.22 & 0.43 & -0.28 & 0.54 & $-0.10^{*}$ & 1.65 & $0.23^{*}$ & 1.94 & 0.15 & 1.33 \\
\hline Utilities & -0.24 & 0.78 & -12.45 & 0.02 & -12.75 & 0.02 & -0.06 & 0.28 & 0.08 & 0.07 & $\begin{array}{c}-0.32 \\
-0.3\end{array}$ & 0.32 & 0.09 & 0.84 & $-0.45^{* * *}$ & 2.08 & $-0.46^{* * *}$ & 2.11 \\
\hline Construction & $-1.47^{* * * *}$ & 9.01 & 0.52 & 1.36 & 0.26 & 0.68 & $-1.04^{* * * * *}$ & 11.53 & 0.09 & 0.31 & $\begin{array}{c}-0.14 \\
\end{array}$ & 0.46 & $-0.43^{* * * *}$ & 10.78 & 0.08 & 0.99 & 0.04 & 0.51 \\
\hline Commercial & $0.23^{* * * *}$ & 5.07 & $-1.1^{* * * * *}$ & 3.23 & $-1.40^{* * * *}$ & 3.87 & $0.28^{* * * *}$ & 8.75 & $-0.78^{* * * *}$ & 3.64 & $-1.04^{* * * *}$ & 4.82 & $0.43^{* * * *}$ & 20.63 & $0.12^{* *}$ & 1.96 & 0.00 & 0.08 \\
\hline $\begin{array}{l}\text { Economic Significance: } \\
\text { SIZE x }(\% \Delta)\end{array}$ & $15.58 \%$ & & $8.61 \%$ & & $-1.16 \%$ & & $13.22 \%$ & & $14.99 \%$ & & $2.87 \%$ & & $54.02 \%$ & & $53.95 \%$ & & $48.39 \%$ & \\
\hline $\begin{array}{l}\text { Economic Significance: } \\
\text { MULTIPLE } 0 \text { to } 1(\% \Delta)\end{array}$ & & & & & $253.9 \%$ & & & & & & $142.1 \%$ & & & & & & $42.17 \%$ & \\
\hline Observations: & 15,379 & & 15,379 & & 15,379 & & 30,657 & & 30,657 & & 30,657 & & 61,295 & & 61,295 & & 61,295 & \\
\hline
\end{tabular}

$*, * *, * * *$ represent significance at the $10 \%, 5 \%$, and $1 \%$ levels, respectively. 
Table 10: Tests of Single-Bank Firm Opacity and Multiple-Bank Distress Hypotheses

\begin{tabular}{|c|c|c|c|c|c|c|c|c|c|c|c|c|c|c|c|c|c|c|}
\hline \multicolumn{19}{|c|}{ Logit Regression: Dependent Variable $=$ MULT } \\
\hline & \multicolumn{6}{|c|}{$\begin{array}{c}\text { Smallest } 25 \% \\
(\leq 10,000 \text { Pesos })\end{array}$} & \multicolumn{6}{|c|}{$\begin{array}{c}\text { Smallest } 50 \% \\
(\leq 33,600 \text { Pesos })\end{array}$} & \multicolumn{6}{|c|}{ All Firms } \\
\hline & \multicolumn{2}{|c|}{ (1) } & \multicolumn{2}{|c|}{$(2)$} & \multicolumn{2}{|c|}{ (3) } & \multicolumn{2}{|c|}{ (4) } & \multicolumn{2}{|c|}{$(5)$} & \multicolumn{2}{|c|}{ (6) } & \multicolumn{2}{|c|}{ (7) } & \multicolumn{2}{|c|}{$(8)$} & \multicolumn{2}{|c|}{ (9) } \\
\hline & Coef & $\mathrm{t}-\mathrm{Stat}$ & Coef & t-Stat & Coef & t-Stat & Coef & t-Stat & Coef & t-Stat & Coef & t-Stat & Coef & t-Stat & Coef & t-Stat & Coef & t-Stat \\
\hline Intercept & $-6.34^{* * * * *}$ & 12.55 & $-5.75^{* * * *}$ & 10.53 & $-5.82^{* * * *+}$ & 10.63 & $-10.0^{* * * * *}$ & 47.46 & $-10.15^{* * * *}$ & 44.04 & $-10.3^{* * * *}$ & 44.31 & $-8.88^{* * * *}$ & 113.94 & $-8.87^{* * * * 1}$ & 105.25 & $-8.93^{* * * *}$ & 104.5 \\
\hline LNSIZE & $0.41^{\text {***** }}$ & 7.00 & $0.35^{* * * *}$ & 5.46 & $0.34^{* * * *}$ & 5.41 & $0.84^{* * * * *}$ & 37.89 & $0.86^{* * * * 4}$ & 35.47 & $0.86^{* * * * *}$ & 35.52 & $0.72^{* * * * *}$ & 104.12 & $0.73^{* * * * *}$ & 96.01 & $0.73^{* * * *}$ & 95.91 \\
\hline DELINQ & & & $-3.39^{* *}$ & 2.30 & $-3.42^{* * *}$ & 2.32 & & & 0.40 & 0.68 & 0.31 & 0.52 & & & -0.12 & 0.55 & -0.11 & 0.53 \\
\hline LNSIZE*DELINQ & & & $0.36^{* *}$ & 2.12 & $0.37^{m * 2}$ & 2.13 & & & -0.09 & 1.44 & -0.08 & 1.30 & & & $-0.04^{*}$ & 1.76 & $-0.04^{*}$ & 1.81 \\
\hline BNKNPL10\%PRI & & & & & $0.17^{*}$ & 1.98 & & & & & $0.24^{* * * * *}$ & 4.77 & & & & & $0.12^{* * * * *}$ & 3.55 \\
\hline BNKLEV10\%PRI & & & & & $0.61^{* * * *}$ & 2.90 & & & & & $0.58^{* * * * *}$ & 4.41 & & & & & $0.30^{* * * *}$ & 3.44 \\
\hline BNKROE10\%PRI & & & & & $0.95^{* * * *}$ & 2.76 & & & & & $0.81^{* * * *}$ & 3.53 & & & & & 0.03 & 0.23 \\
\hline FOREIGNPRI & $0.37^{\text {***** }}$ & 6.44 & $0.38^{* * * * *}$ & 6.59 & $0.41^{n+m+n}$ & 6.85 & $0.40^{* * * *}$ & 11.73 & $0.41^{* * * *}$ & 11.87 & $0.44^{* * * *}$ & 12.64 & $0.31^{* * * *}$ & 13.49 & $0.32^{* * * *}$ & 13.77 & $0.34^{* * * * *}$ & 14.28 \\
\hline BNKASSET10\%PRI & 0.00 & 0.03 & 0.01 & 0.15 & 0.08 & 1.27 & $0.13^{\text {**** }}$ & 3.74 & $0.13^{* * * *}$ & 3.98 & $0.21^{* * * * *}$ & 5.87 & $0.16^{* * * *}$ & 7.09 & $0.16^{* * * *}$ & 7.20 & $0.20^{* * * *}$ & 8.20 \\
\hline Agriculture & $1.21^{* * * * *}$ & 15.98 & $1.19^{* * * * *}$ & 15.74 & $1.24^{* * *+4}$ & 15.96 & $0.98^{* * * *}$ & 21.43 & $0.95^{* * * *}$ & 20.60 & $1.00^{* * * *}$ & 21.32 & $0.87^{* * * *}$ & 30.25 & $0.84^{* * * *}$ & 28.92 & $0.86^{* * * * *}$ & 29.18 \\
\hline Fishing & $1.62^{\text {***** }}$ & 3.17 & $1.67^{* * * *}$ & 3.27 & $1.66^{* * a+4}$ & 3.21 & $0.73^{\text {*** }}$ & 2.00 & $0.72^{*}$ & 1.98 & $0.74^{* * *}$ & 2.03 & $0.73^{\text {******* }}$ & 3.19 & $0.74^{\text {***** }}$ & 3.21 & $0.75^{* * * *}$ & 3.26 \\
\hline Mining & $2.16^{* * * * *}$ & 16.81 & $2.20^{* * * *}$ & 16.98 & $2.21^{k * n+4}$ & 17.03 & $1.90^{* * * *}$ & 20.42 & $1.93^{* * * * *}$ & 20.57 & $1.94^{* * * *}$ & 20.64 & $1.76^{* * * *}$ & 25.26 & $1.78^{* * * * *}$ & 25.41 & $1.78^{* * * *}$ & 25.40 \\
\hline Utilities & $1.79^{* * * *}$ & 7.35 & $1.79^{* * * *}$ & 7.34 & $1.80^{n+m e n t}$ & 7.37 & $1.56^{* * * *}$ & 9.11 & $1.53^{* * * *}$ & 8.86 & $1.52^{* * * *}$ & 8.79 & $1.09^{* * * *}$ & 9.07 & $1.05^{* * * *}$ & 8.69 & $1.04^{* * * *}$ & 8.67 \\
\hline Construction & $1.19^{* * * *}$ & 12.38 & $1.19^{* * * *}$ & 12.41 & $1.22^{* * * *}$ & 12.60 & $1.10^{* * * *}$ & 19.51 & $1.11^{* * * *}$ & 19.66 & $1.13^{* * * *}$ & 19.94 & $0.89^{* * * *}$ & 24.25 & $0.90^{* * * *}$ & 24.56 & $0.91^{* * * *}$ & 24.67 \\
\hline Commercial & $0.99^{\text {***** }}$ & 17.29 & $0.98^{* * * *}$ & 17.25 & $0.99^{* * * 4}$ & 17.38 & $1.14^{\text {**** }}$ & 34.89 & $1.13^{* * * * *}$ & 34.55 & $1.14^{* * * * *}$ & 34.71 & $1.26^{* * * *}$ & 57.42 & $1.26^{* * * *}$ & 57.07 & $1.26^{* * * *}$ & 57.10 \\
\hline $\begin{array}{l}\text { Economic Significance: } \\
\text { SIZE } \times 2(\% \Delta)\end{array}$ & $27.70 \%$ & & $27.65 \%$ & & $27.03 \%$ & & $53.25 \%$ & & $53.59 \%$ & & $53.71 \%$ & & $28.24 \%$ & & $28.38 \%$ & & $28.38 \%$ & \\
\hline & & & & & & & & & & & & & & & & & & \\
\hline Observations: & 15,379 & & 15,379 & & 15,379 & & 30,657 & & 30,657 & & 30,657 & & 61,295 & & 61,295 & & 61,295 & \\
\hline
\end{tabular}

$*, * *, * * *$ represent significance at the $10 \%, 5 \%$, and $1 \%$ levels, respectively. 